\title{
DESIGN OF A UNIAXIAL LOAD CREEP \\ TESTING MACHINE
}

Kaung Jain Chang and R.H. Lance

Department of Theoretical and Applied Mechanics

Cornel1 University

Ithaca, N.Y. 14853

ERDA Report 非00-2733-10

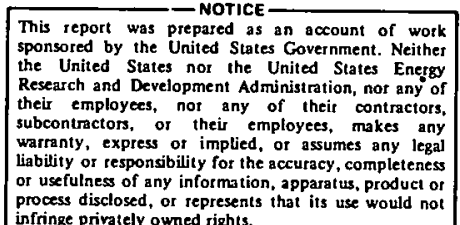

sponsored by the prepased as an account of work

the United States nor the United States Energy

their employeess warranty, ex, or their employees, makes any the usefor process disclosed, or represents that its use would not infringe privately owned rights.

May 1977

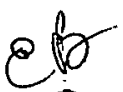

DISTRIBUTION OF THIS. DOCUMENT IS UNLIMITED 


\section{DISCLAIMER}

This report was prepared as an account of work sponsored by an agency of the United States Government. Neither the United States Government nor any agency Thereof, nor any of their employees, makes any warranty, express or implied, or assumes any legal liability or responsibility for the accuracy, completeness, or usefulness of any information, apparatus, product, or process disclosed, or represents that its use would not infringe privately owned rights. Reference herein to any specific commercial product, process, or service by trade name, trademark, manufacturer, or otherwise does not necessarily constitute or imply its endorsement, recommendation, or favoring by the United States Government or any agency thereof. The views and opinions of authors expressed herein do not necessarily state or reflect those of the United States Government or any agency thereof. 


\section{DISCLAIMER}

Portions of this document may be illegible in electronic image products. Images are produced from the best available original document. 


\begin{abstract}
The design of a uniaxial load creep machine for testing small scale metallic structures such as beams, plates and thin-walled cylinders is described in detail. A special drum device introduced first by Hart is utilized to achieve step loading during creep tests. Some proof test results on four-point bending beams at room temperature are presented. It is noted that the specimen temperature can be controlled within a $\pm_{0.2}^{\circ} \mathrm{C}$ fluctuation. Measurements of displacements exhibited creeplike behavior in the range of loads and times considered.
\end{abstract}




\section{INTRODUCTION}

Experimental efforts provide information not only in the evaluation of material properties but also in testing the foundations upon which analytical techniques are based. In the past few decades, testing of creep of structures other than uniaxial tests has gradually received attention from investigators in the field of solid mechanics. MacCullough [1], Tapse11 and Johnson [2], Martin and Zwissler [3] have investigated creep in lead and aluminum beams subjected to pure bending at room temperature and justified that a plane section remains plane during creep deformation; Davis [4] has made tests on steel beams under pure bending at temper-. atures of 1500 and $1600^{\circ} \mathrm{F}$; Strum, Dumont and Howell [5] have reported creep tests on catilever aluminum beams. of constant strength; Sim and Penny [6] have performed room temperature tests on pure bending beams and circular plates under constant and variable concentrated loading during creep; Sidebottom and colleaques $[7,8,9]$, have reported tests on torsion-tension members and thick-walled cylinders under internal pressure and axial load; A.E. Johnson et. al. $[10,11]$ have performed various multi-axial creep tests; Targaard and Jones [12] have made room temperature creep tests on clamped circular lead plates under constant uniform lateral load; and Storakers [13] has studied creep tests on a circular membrane of magnesium alloy. Still, more reliable testing data and techniques are needed for the improvement of understanding material properties and development of analytical and design techniques.

The purpose of the present investigation is to study experimentally the creep phenomena of metal structures at elevated temperatures. The objective is to collect creep testing data of vairious small scale metallic 
structures in order to evaluate the modern and classical theories and to develop inhouse structural experimental expertise as a basis for further, more detailed and realistic experimental studies. In our creep test laboratory, we have built up a multi-purpose load frame to perform creep tests at elevated temperatures for different small scale metallic structures. A mechanical device is used to achieve reproducible step-loading cycles for al1 tests. At the present stage, creep tests on pure bending of beam specimens at room temperature have been performed; some equipment necessary for the performance of other mentioned tests is not yet available. The accomplishment of all these tests constitutes the goal of our future investigation.

In this report, the design and operating principles of all mechanical parts of the testing equipment for each structure are described, and the electronic instruments such as transducers, data acquisition system, and temperature control system are described. . Results of several proof tests for creep of beams under step loading at room temperature are also discussed. Although it is desirable in view of modern engineering practice to use exclusively SI units, mixing of English and. SI units in this work was unavoidable because of current shop practice. 


\section{THE UNIAXIAL LOAD CREEP TESTING MACHINE}

Figure 1 shows the schematic arrangement of the creep testing machine and a block diagram of the data acquisition and analysis system. All equipment is enclosed in a well insulated room with a temperature control system to maintain the temperature in the room close to $22^{\circ} \mathrm{C}$. In addition, the specimen is enclosed in an environmental chamber during creep tests.

The load is applied to the specimen from the drum device by means of a flexible steel strap, as shown. Hence, the machine is capable of applying tensile axial force only. The load fixture is connected to the drum device and the load cell by the pulling rods; to test a different structural element, different rods and load fixture must be used. Utilizing the drum device, we are able to perform creep tests under a typica? reproducible cyclic-loading as shown in fig. 1C. By use of the transducers in connection with the data acquisition system (fig. $1 b$ ), data consisting of the load, the deformation and the temperatures as functions of time are collected by an IBM compatible magnetic tape recorder; then, by use of the IBM $370 / 168$, these data are analyzed and plotted as functions of time.

Figures 2 and 3 are photographs of the equipment for pure bending beam test; in particular fig. 2 shows the load frame, the load fixture, the transducers, and the drum device. while fig. 3 shows the digital data acquisition system $(A, B)$, the power supplies (C), and the room temperature controller (D).

The creep testing system mentioned above consists of five modules; these are the temperature control systems, the data acquisition system, the load applying system, the measuring devices - transducers, and the load fixtures for creep test of each different structures. A detailed description of these modules is presented below. 


\section{A. The Temperature Control System}

There are two temperature control systems used in our laboratory; one is for room temperature control, the other is for the control of the environmental chamber used in the elevated temperature testing.

A steady room temperature is important in order to obtain steady output from the power supplies and steady signals from the transducers. The control of the room temperature is accomplished by use of a window air conditioner (6000 BTU, made by Carrier), an electrical heater (1500 watts, made by Markel), and a circuit ( $D$ in $\mathrm{fig}$. 3) with a thermostat to control the heater. Moreover, we use a fan inside the room to circulate the air.

For the elevated temperature creep test, a high precision Instron Environmental Test Chamber, Mode1 A74-37, is available, however the temperature controller of this unit is not yet available. The operating temperature range of this chamber is from $-73^{\circ} \mathrm{C}$ to $340^{\circ} \mathrm{C}$; the temperature is controllable to within $\pm 0.5^{\circ} \mathrm{C}$; the temperature variation, from the top to the bottom of the instrument, can be maintained within a tolerance of $\pm 1^{\circ} \mathrm{C}$. The rheometer of the test chamber has an operating range of $10^{\circ} \mathrm{C}$ to $340^{\circ} \mathrm{C}$. The inner dimensions of the chamber are $11^{\prime \prime} \times 7:-3 / 4^{\prime \prime} \times 22^{\prime \prime}$; the load fixtures are designed to fit inside this chamber, and the load frame is also designed to hold the $70 \mathrm{lb}$ chamber securely. Detailed description of this instrument can be found in [14].

During elevated temperature tests, great care must be taken to protect the transducers from being overheated by the heat conducted along the pulling rods. This can be achieved by use of a water cooling system, which consists of a pipe wound around the pulling rods and a water pump circulating cold. water through the pipe. 
For room temperature tests, the temperature chamber is used only for damping the temperature fluctuation in the space-surrounding of the specimen. Instead of using the Instron chamber, we have made a plywood chamber with fiber glass insulation, which is shown in fig. 2. The wooden chamber has a bigger working space; through its use the temperature can be controlled within $\pm 0.2^{\circ} \mathrm{C}$.

\section{B. The Data Acquisition System}

The purpose of the data acquisition system is to automatically measure and to store for permanent record, time, forces, displacements and temperature over a period of time as long as 400 hours, a period judged to be necessary for complete creep tests. The sampling frequency would need to be low when changes were not occurring abruptly and high when sudden changes; such as step loading, took place.

The system selected consists of an Acurex Autodata Nine and a Cipher Series H Magnetic Tape Recorder (model $85 \mathrm{H}$ ). A photograph of these units is shown in fig. 2. The Accurex Autodata Nine is a high resolution, multipurpose, multichannel data acquisition instrument. It collects signals automatically from various kinds of transducers and records them in digital

form as functions of time. The use of the magnetic tape recorder together with the Accurex Autodata Nine improves the recording speed from 2.4 per channels to 24 channels per second. Thus sufficient amounts of data can be collected during fașt load changes. The system can monitor up to 40 channels and can be easily expanded to 1000 channels by adding Autodata 616 scanners (option A916). The crystal clock (option A906) built into the Autodata Nine has an initial accuracy of $\pm 0.023 \%$, and stability of $\pm 0.002 \% /{ }^{\circ} \mathrm{C}$ and $0.005 \%$ per month. 
The Acurex Autodata Nine includes a high resolution $(0.001 \%$ of fullscale range) guarded IDVM (Integral Digital Voltmeter, option A904) to convert the conditioned sensor voltage into digital data. Signals other than voltage, therefore, need some circuit or instrument to convert them into voltages before being sensed by the IDVM. The IDVM is autozeroing and has an absolute accuracy of $0.005 \%$ range + readings, it operates on the Autodata's patented V-F conversion technique, which integrates the voltage over one period of the power line frequency; this bipolar integration makes the reading insensitive to noise induced to the sensor cable.

The thermocouple input module used in Autodata Nine has guarded icepoint compensation circuits. which detect and correct the thermal EMF developed at the imput connections so that the Autodata Nine measures the true data point temperature in degree $\mathrm{C}$ or $\mathrm{F}$.

The digital data collected by the Acurex Autodata Nine can be displayed in various ways. Data of all channels as well as the current time can be selected to be displayed on the front panel; for systematic records, options such as the printer (A931), the magnetic tape recorder (A933), the paper tape recorder (A934), the cassette recorder (A936), and the calculator (A941) are available to mate with the Autodata Nine. Mating the Autodata Nine with the Tektronix 31 or with the Hewlett-Packard 9800-series prograrmmable calculators, provides on-site data aquisition and processing system. Detailed information about the Autodata Nine is given in [15] and [16].

Both the magnetic tape recorder and the printer are used to record data. The Ciphers magnetic tape recorder is IBM compatible. Data collected by the magnetic tape are analyzed by use of the IBM 370/168. Note that the recording speed using the magnetic tape alone is 24 channels per second, 
however, that of the printer is only 2.4 channels per second. Therefore, the magnetic tape is used alone to monitor during fast loading change. Otherwise both the magnetic tape and the printer are used. Thus, the printer can be used as a check during tests. Details of these units can be found in [15].

\section{The Loading System}

The loading system consists of the load frame, which supports and transmits the load, and the drum device by means of which step loading can be achieved.

Figure 4a shows the front and side views of the system with the load cell (L), the environmental chamber (C), the load fixture (F), and the drum device (D) in operating position. As shown in the diagram, the load cell is mounted in a load cell housing $(H)$. which is connected to the top panel of the load frame; a universal joint is located between load cell and the rod (R); the pulling rods together with the load fixture pass through the temperature chamber and connect with the drum device by a turn buckle (T) which is used for length adjustment; weights $\left(W_{1}, W_{2}\right)$ are hung on each side of the drum to produce torque in the drum and, hence, an axial load on the system. Fig. 4b shows cross-sectional views of the system indicated in fig. 4a. Fig. 5 is a detailed drawing of the load cell housing. The universal joint is used to eliminate bending effect on the load cell in case of any misalignment in the system.

The drum device consists of two concentric aluminum cylinders with diameters of 4" and 2", respectively, connected to a steel shaft as shown in fig. 1b. Two ball bearings support the cylinder and permit free rotation 
about the steêl shaft which is locked onto the load frame as shown in fig's. 1b and 4a. Four steel blades are mounted on the surface of the 12 " cylinder to support the weights. Another steel blade is mounted tangential to the 4 " section to transmit load to the pulling rod. With $W_{1}>W_{2}$ the resultant torque in the cylinder assembly transmits a force $F=3\left(W_{1}-W_{2}\right)$ to the pulling rod. Thus, adding or removing weights according to a prepared schedule will produce the desired step loading in the creep tests. Note that the factor 3 between the diameters of the two cylinder sections reduces the weight we have to handle each time we change the loads. It will be shown in the last section that it takes no more than one second to complete a load change.

In the present system, level adjustments of the load frame, the temperature chamber, the drum device and the load cell housing are separate. To align the system properly, we first level the load frame (fig. 4) by adjusting the six bolts (B3) on the bottom of the frame; underneath each of the six bolts there is a 4" $x 4^{\prime \prime}$ steel plate and two 4" $x$ 4" Barrymount pads (Barry Products) for shock absorption; according to the specification, a single layer of the padmount will support 50 psi at approximate natural frequency of $18 \mathrm{~Hz}[17]$. Second, we level the load cell housing by means of four bolts in the housing plates before locking it to the loading frame. Third, the beams (BI) supporting the temperature chamber are adjusted by means of bolts fastened to the frame as shown in Fig. 4a. Finally, the drum device is adjusted by means of leveling screws similar to those used in the third step. 


\section{The Transducers and Power Supplies}

The three basic transducers used are DC-LVDT's (Linear Variable Differential Transformer) for displacements, load cell for the applied load, and thermocouples for temperatures. In addition, we intend to use bonded resistance strain gages in the future for detailed strain measurements on plates and cylinders. The principal physical features and specifications of the above transducers are described below.

For displacement measurements, we use Schaevitz Engineering PC series, precision gage heads, denoted GPD-121-125 and GCD-121-050 [18]. The DC-operated gage head incorporates the core, the LVDT, and all necessary electronics in one housing; as shown in fig: $6 \mathrm{~A}$, the core is connected to a spring-loaded probe shaft, which is guided in a sleeve bearing. The case is threaded externally to simplify mounting. According to the specifications, the gage head has a repeatability of $0.000025^{\prime \prime}$, and a linearity of $\pm 0.25 \%$ of full range. The transducer requires a $\pm 15 \mathrm{~V}$ DC input which produces an output of $\pm 10 \mathrm{~V} D C$ at full range. The power supply used for this purpose is . a Trans Tek DC dual output supply [19] model D15.200, as shown in $\mathrm{fig} .2$. It supplies steady \pm 15 DC power with a typical temperature coefficient of $0.015 \% /{ }^{\circ} \mathrm{C}$ and a maximum ripple noise of $1 \mathrm{mV}$ RMS.

For load measurements, we have selected a Transducers Six Series Model 62/63 low capacity tension compression load cell [19]. This $226 \mathrm{~kg}$. load cell has zero balance of $\pm 1 \%$, repeatability of $0.01 \%$ full scale, linearity of $\pm 0.05 \%$ full scale, temperature effect on output of $\pm 0.08 \%$ of $10 a d / 100^{\circ} \mathrm{F}$, temperature effect on zero of $0.15 \%$ of full scale $/ 100^{\circ} \mathrm{F}$, and needs an excitation voltage of $10 \mathrm{~V} \mathrm{DC}$. The power supply used for the load cell is a 
Kepco model $\mathrm{ABC}$ 10-0.75(M) regulated DC supply [20]. This transistor power supply is programmable to maintain any level within its rated range and to be fully loaded at any output setting. It has a temperature output effect of $<0.05 \% /{ }^{\circ} \mathrm{C}$.

The type-K thermocouple were fabricated according to the ASTM standard [21], by welding two No. 20 (0.032" diameter) wires of chromel (+) and Alumel (-) at one end. These thermocouples can be used in the range of $-40^{\circ} \mathrm{C}$ to $+980^{\circ} \mathrm{C}$ in normal atmospheres. The detailed information of thermocouples can be found in [21].

We intend to use bonded resistance strain gages in the future to measure strain on the surface of structural elements such as plates and cylinders. They can be used together with the LVDT's to provide more detailed descriptions of deformation. Furthermore, strain gages can be used at elevated temperature to replace the much more expensive high-temperature LVDT. Finally, strain gages are more convenient to use in high-temperature tests because of space restrictions in the environmental chamber. In order to use the Autodata Nine for data acquisition, the signal produced by the strain gage must be converted into voltage; a device for this purpose is available from Acurex Inc.

\section{E. The Load Fixtures}

Our original intention was to conduct experiments on a variety of structure elements such as beams, plates and cylinders. To date we have designed and constructed a fixture for four point bending of slender beams and a fixture for testing clamped annular plates. In addition, a fixture has been designed but not constructed for testing thin-walled tubes under axial load and internal pressure. The designs are described below. 


\section{1) Four Point Bending Beam Fixture}

As mentioned above, experiments on beams in pure bending have been studied by many investigators $[1,2,3,6,22]$; several experimental setups have been introduced. In the present study, we have designed a loading fixture which incorporates features not reported in the literature including several mechanisms designed to reduce friction at the contact points. Some preliminary results from tests on pure bending of nickel beam specimens are presented in the next section.

The load fixture is shown in fig's 7 and 8 . Fig. $7 a$ shows the beam supporting fixture, fig. 7b shows the load applying rod, and fig. 8 shows the loading bars and the LVDT holder. The assembly can be seen in fig. 2 . Two loading bars are placed into the holes at equal distance from the symmetric plane of the beam supporting fixture and the loading rod respectively. A beam is shown in the loading configuration in fig. 9, in which the solid circles represent the positions of the loading bars. In this way, a four-point-bending test is achieved. Note that the distance between the loading bars can be changed by placing them in different holes in the fixture, providing that symmetry is maintained.

The loading bars, as shown in Fig. 8a, are specially designed for eliminating frictional force at the contact points. Note that the main portion of the bar has a sleeve loosely fitted on it and free to rotate about it. This reduces most of the induced friction which may be significant in the case of knife edge contact as used in [6], [21].

Three LVDT's are used to measure the displacements at the center and at two side points, equidistant from the center within the range of the pure bending of the beam. The position of the LVDT holder and the points of measurement are shown as solid triangles in fig. 9. Since the shape 
of the beam under pure bending is a circular arc, measurements of three displacements as functions of time are adequate to determine the curvature as a function of time. Since the whole system is symmetric to the center line, the displacements measured at the two side points are expected to be equal. This serves a check of our measurements. The LVDT's at service positions can be seen clearly in fig. 2 .

\section{2) Clamped Circular Annular Plate Fixture:}

Fig. 10 shows the load fixture for testing of an annular circular plate which is shown shaded. The annular specimen is clamped at both its outer edge and inner edge as shown. The transverse load is applied by means of the central rod which forms a part of the clamping device. This fixture is designed to fit our loading system as well as in the Instron environmental chamber.

As shown in fig. 10, four DC-LVDT's can be installed to measure the appropriate displacement. In this regard, the relative displacement of two points can be recorded; this can be used to check analytical solutions if available. It is noted that the bonded resistance strain gage may be more useful in the interpretation of creep data collected. Because of its small size, the bonded resistance strain gage or rossette can be placed at different positions and in different directions to obtain more detailed deformation data.

\section{3) Thin-Walled Cylinder Fixture}

A tentative design of a fixture to test thin-walled cylinders in creep is shown in Fig. 11. Note that allowance has been made in the grip to introduce fluid for developing internal pressure and for connection to the pulling rods of the testing machine described above. Because of space 
limitation and location flexibility it is intended that strain gages be used to measure deformation of the specimen. 
III. PROOF TEST

A. Preliminary Considerations

Before conducting controlled experiments on the new system it is necessary to conduct "proof" tests to determine whether it has met the design objectives. To this end we have conducted, to date, two complete preliminary tests on creep of pure nickel specimens under pure bending at room temperature.

The material chosen for testing was an one-inch diameter pure nickel (Ni 270) rod obtained from the International Nickel Company. This was chosen because the same material is being used by another research group at Cornell in a program of intensive investigation of its mechanical properties. Using pure nickel, they have obtained a complete set of the material parameters which appear in Hart's Theory [23]. This makes analysis of the problem using Hart's Theory straight forward. The composition of the pure nickel is given in Table 1. Rectangular beam specimens were machined from the nickel rod to $7 "$ × $0.8^{\prime \prime} \times 0.125^{\prime \prime}$ which is approximately $177.8 \mathrm{~mm}$ $\times 20 \mathrm{~mm} \times 3.2 \mathrm{~mm}$.

Table 1. Chemical Analysis of Specimen (Ni 270)

$\begin{array}{cc}\text { Composition } & \text { Percentage } \\ \mathrm{Ni} & 99.98 \\ \mathrm{C} & -0.01 \\ \mathrm{Mn} & <0.001 \\ \mathrm{Fe} & 0.003 \\ \mathrm{~S} & <0.001 \\ \mathrm{Si} & <0.001 \\ \mathrm{Cu} & <0.001 \\ \mathrm{Cv} & <0.001 \\ \mathrm{Ti} & <0.001 \\ \mathrm{Co} & <0.001\end{array}$


Before the two tests a careful calibration of the LVDT's was conducted. A Hewlett Packard SI unit calibrator which can read lengths to within 0.005 $\mathrm{mm}$ was used. Curves of the calibration are shown in fig's $12 \mathrm{a}, \mathrm{b}$ and $\mathrm{c}$. It is easy to see that each LVDT has a linear range of operation, although they are individually different in range and slope. Our primary concern here is in verifying the linearity of the range and its extent.

The next step in our evaluation of testing machine performance was to evaluate, the ability of the system to respond to a "step load." This loading history is achieved by either adding or removing weights from the drum loading device described above. Figure 13 shows typical load cell output on removal or addition of load. It is noted that a step load can be achieved consistantly in a time of about one second. The over shoot and load fluctuation on the rising step load results from inertia in the system, we believe. The data shown in $\mathrm{f}_{\mathrm{ig}}$. 13 was collected on the magnetic tape recorder.

B. Tests and Results

The first proof test was run at room temperature on a beam specimen with dimensions $0.080^{\prime \prime} \times 0.8^{\prime \prime} \times 7.0^{\prime \prime}(2.03 \mathrm{~mm} \times 20.3 \mathrm{~mm} \times 177.8 \mathrm{~mm}$.), for a duration of 243 hours. During this test the room, and hence specimen, temperature was not controlled. Figures 14, 15, 16 and 17. show the temperature, the load (and hence applied moment), the displacements and the calculated curvature, as functions of time, respectively. All data were collected on printed paper tape, transcribed to punched cards and plotted by the computer.

In fig. 14 it can be seen that, without control, the temperature in the environmental chamber fluctuated in the range of $25^{\circ}$ to $29^{\circ} \mathrm{C}$, in accord 
with the outside (room) temperature which was in the range of $21^{\circ}$ to $29^{\circ} \mathrm{C}$. During the second proof test, described below, the temperature fluctuation was reduced. Figure 15, which is the load cell output, shows how the load cell responds to temperature change, during the first test.

In figs. 16 and 17 are shown displacement curvature histories corresponding to the load (moment) history of fig. 15. Curvature was obtained from the three displacement measurements by a simple calculation as follows. Referring to fig. 18, where $S$ is the machined exact distance and $\delta$ the measured relative displacement between the two adjacent LVDT's, assuming the shape of the beam under pure bending is a circular arc, from $\triangle O B C$,

$$
S^{2}+(R-\delta)^{2}=R^{2}
$$

and thus the curvature

$$
\mathrm{K} \equiv \frac{1}{\mathrm{R}}=\frac{\mathrm{s}^{2}+\delta^{2}}{2 \delta}
$$

Although smooth displacement response was expected, we experienced some step-1ike behavior in displacement measurements for $t<55$ hours (fig. 16). The curvature of course exhibits a similar phenomenon. This we believe to be due to friction at the contact points of the loading bar and the beam. (As we note below the displacement measurements of the second proof test are smooth in all load ranges.) The difference in displacement readings in the interval $160<$ time $<230$ hours we believe to be due to deviation of a side LVDT from its calibrated behavior. Attempts are being made to verify this. Unloading data is not available. 
The beam exhibited creep-like behavior in the range of loads and times considered here. However, we will not discuss this in detail because of the limited data available.

The second proof test was condicted, at controlled room temperature, on a rectangular beam specimen with dimension $0.125^{\prime \prime} \times 0.8^{\prime \prime} \times 7.0^{\prime \prime}(3.18 \mathrm{~mm}$ x $20.3 \mathrm{~mm} \times 177.8 \mathrm{~mm}$ ) for a duration of over 900 hours. Test results are shown in figures 19 and 20.

In the second test an attempt. was made to control the temperature history, which is shown as $\mathrm{T} 1$ and $\mathrm{T} 2 \mathrm{in}$ fig. 20.' $\mathrm{T} 1$ is the temperature measured near the sensor of the heating/cooling controller,first $(t<600$ hrs.) located outside of the environmental chamber, and $\mathrm{T} 2$ is the temperature near the specimen in the chamber. The smooth temperature behavior after $t=600$ hours was achieved by placing the temperature sensor of the heating/cooling control system within the environmental chamber. Note that the temperature fluctuation has less influence on the load cell output than in the first test. We believe that the load cell was in a part of the room which underwent smaller temperature fluctuation than the sensor, in this second test. The load cell specifications assure us that fluctuations caused by temperature change are within $0.08 \%$ of $10 a d$ per $100^{\circ} \mathrm{F}$.

In Figure 19 are shown the displacement histories corresponding to the loading history of $\mathrm{fig}$. 20. Note the relatively smooth transition zones in the displacements in response to step changes of load. The slight fluctuations in displacement (see $550<$ tiem $<750$ hours) remain somewhat less than those experienced in the first test. We have no data yet on the response of the system using the newly designed loading sleeves described above. 
The general behavior of the beam is the same here as in the first test. There appears to be creep in the specimens, but in the absence of unloading history a quantitative description can not be given.

ACKNOWLEDGEMENTS

This research was supported by Contract No. EY-76-S-02-2733 of the Energy Research and Development Administration, Washington, D.C. with Cornel1 University, Ithaca, N.Y. 14853. 


\section{References}

1. G.H. MacCullough, "An Experimental and Analytical Investigation of Creep in Bending," Transactions, Am. Soc. Mechanical Engrs., Vo1. 55, APM-55-9-55 (1933).

2. H.J. Tapse11 and A.E. Johnson, "An Investigation of the Nature of Creep Under Stresses Produced by Pure Flexure," Journal, Inst. Metals (British), Vol. LVIII, No. 2, pp. 121-137 (1935).

3. J. Marin and L.E. Zwissler, "Creep of Aluminum Subject to Bending at Normal Temperatures," Proceedings, Am. Șoc. Testing Mats., Vol. 40, p. 937 (1940).

4. E.A. Davis, "Creep of Metals at High Temperature in Bending," Transactions, Am. Soc. Mechanical Engrs., Vol. 60, A-29 (1938).

5. R.G. Sturm, C. Dumont, and F.M. Howell, "A Method of Analyzing Creep Data," Transactions, Am. Soc. Mech. Engrs., Vol. 58, A-63 (1936).

6. G.M. Sim and R.K. Penny, "Some Results of Testing Simple Structures under Constant and Variable loading During Creep," Experimental Mechanics, Vol.10, pp. 152-159 (1970).

7. S. Dharmarajan and O.M. Sidebottom, "Inelastic Design of Load Carrying Members," University of Illinois, T\&AM Report No. 174, (1960).

8. J.W. Schweiker and O.M. Sidebottom, "Creep of Thick-Walled Cylinders under Internal Pressure and Axiall Load," University of Illinois, T\&AM Report No. 198 (1961).

9. J.L. Gubser and O.M. Sidebottom, "Creep Torsion of Non-Circular Bars," University of Illinois, T\&AM Report No. 198 (1961).

10. A.E. Johnson, "Creep under Complex Stress System at Elevated Temperatures," Proceedings, Inst. Mech. Engrs., Vol. 164, p. 432 (1951).

11. H.J. Tapsel1 and A.E. Johnson, "Creep under Combined Tension and Torsion," Engineering, Vol. 150, (1940).

12. P.T. Tarpgaard, Jr. and Norman Jones, "The Influence of Finite-deformation upon the Creep Behavior of Circular Plates," Int1. J. Mech. Sci., Vol. 14, 447-467 (1966).

-13. B. Storakers, "Finite Creep of a Circular Membrane under Hydrostatic Pressure," Acta Poly., Scandinavica, M.E. Ser. 44. Stockholm (1969).

14. Instron Invironmental Chamber Manual.

15. Acurex Auta Data Catalog. 
16. Acurex Autodata Nine user's Manua1.

17. Barrymount Products Catalog.

18. Schaevitz Engineering, Technical Bulletin 1503.

19. Transducers, Inc., Bulletin 72A.

20. Kepco Power Supply, Catalog 146-1278.

21. ASTM STP 470, "Manual on the Use of Thermocouples in Temperature Measurement," (1970).

22. ASTM STP 566, "Hand Book of Fatigue Testing," (1974).

23. E.W. Hart, C.Y. Li, H. Yamada, and G.L. Wire, "Phenomenological Theory: a Guide to Constitutive Relations and Fundamental Deformation Properties," in 'Constitutive Equations in Plasticity', edited by A. Argon, MIT Press, (1976). 


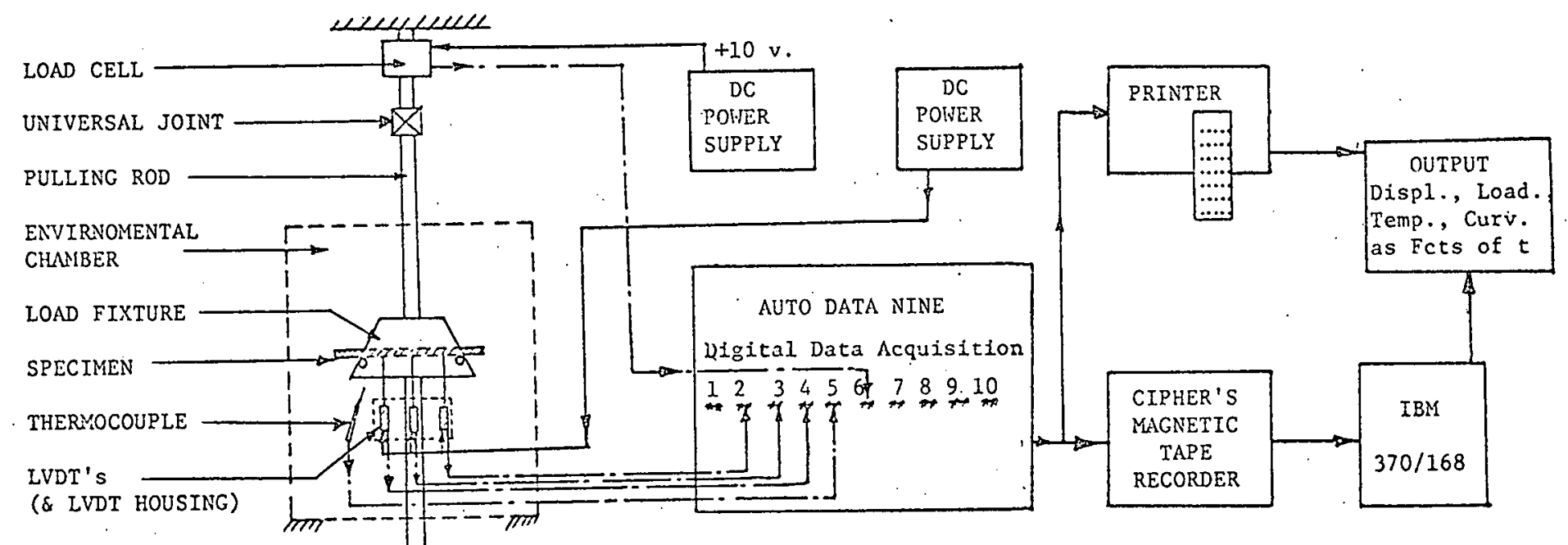

(d) Data Acquisition and Analysis Block Diagram

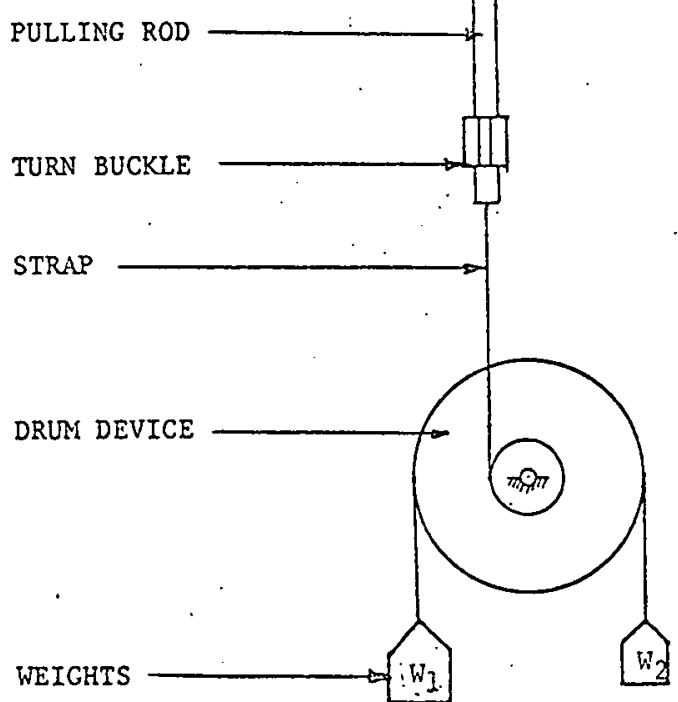

(a) Load System

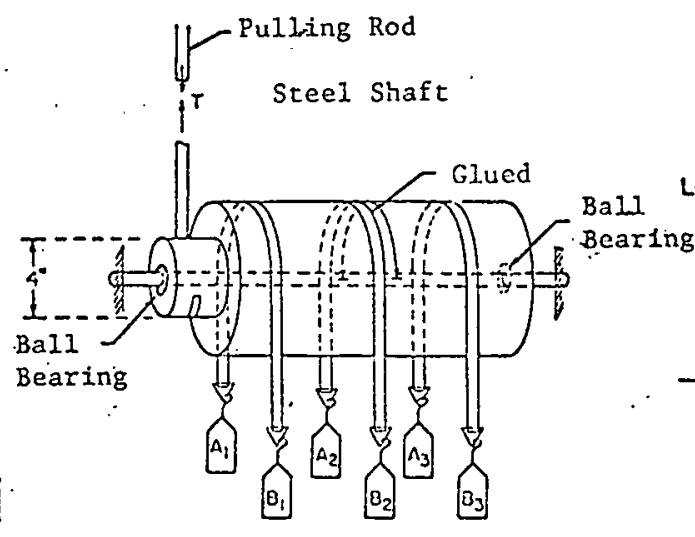

(b) Drum Device

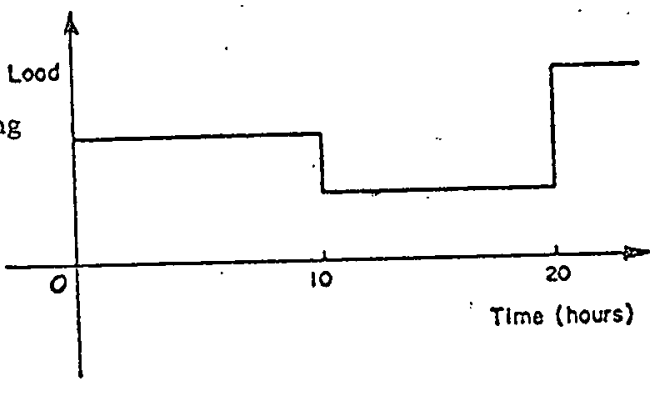

(c) Step Loading Function

Figure 1. Descriptive Diagrams of the Uniaxial Creep Testing System 


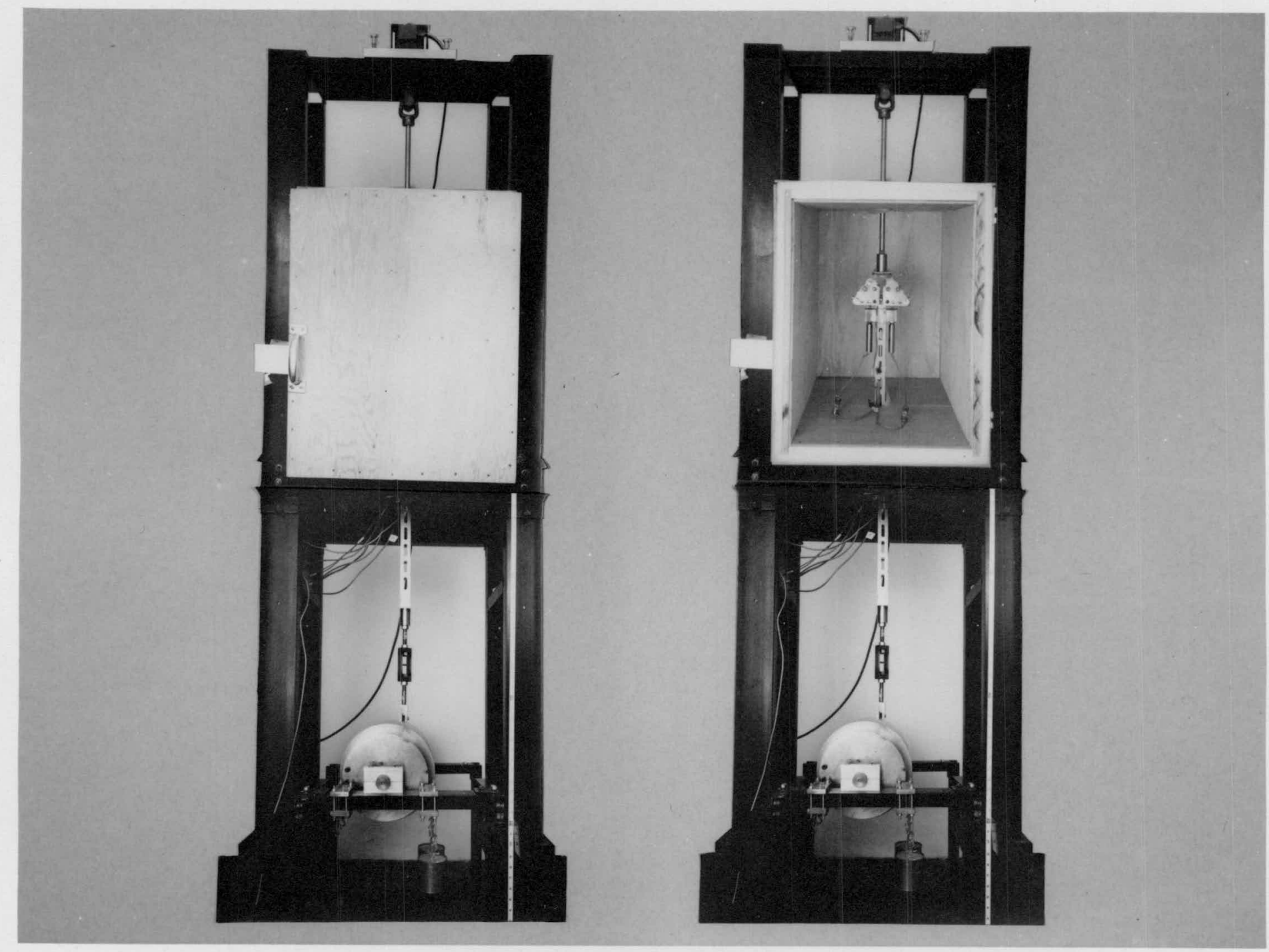

Figure 2. Uniaxial Creep Testing System 



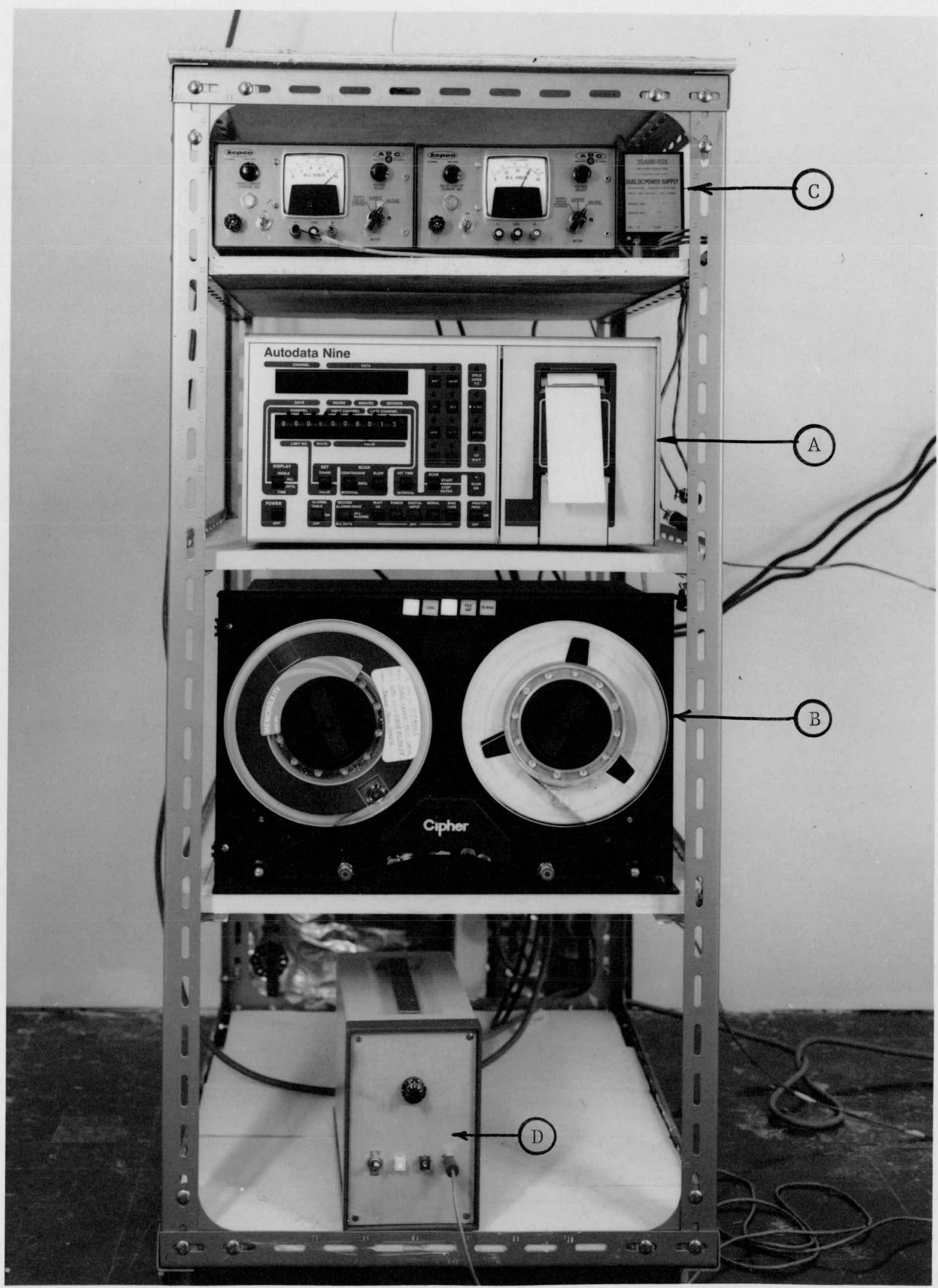

Figure 3. Instruments Used in Creep Tests

A: Auto Data Nine Digital Data Logger

B: Cipher's 85II Magnetic Tape Recorder

C: Power Supplies

D: Room Temperature Controller 



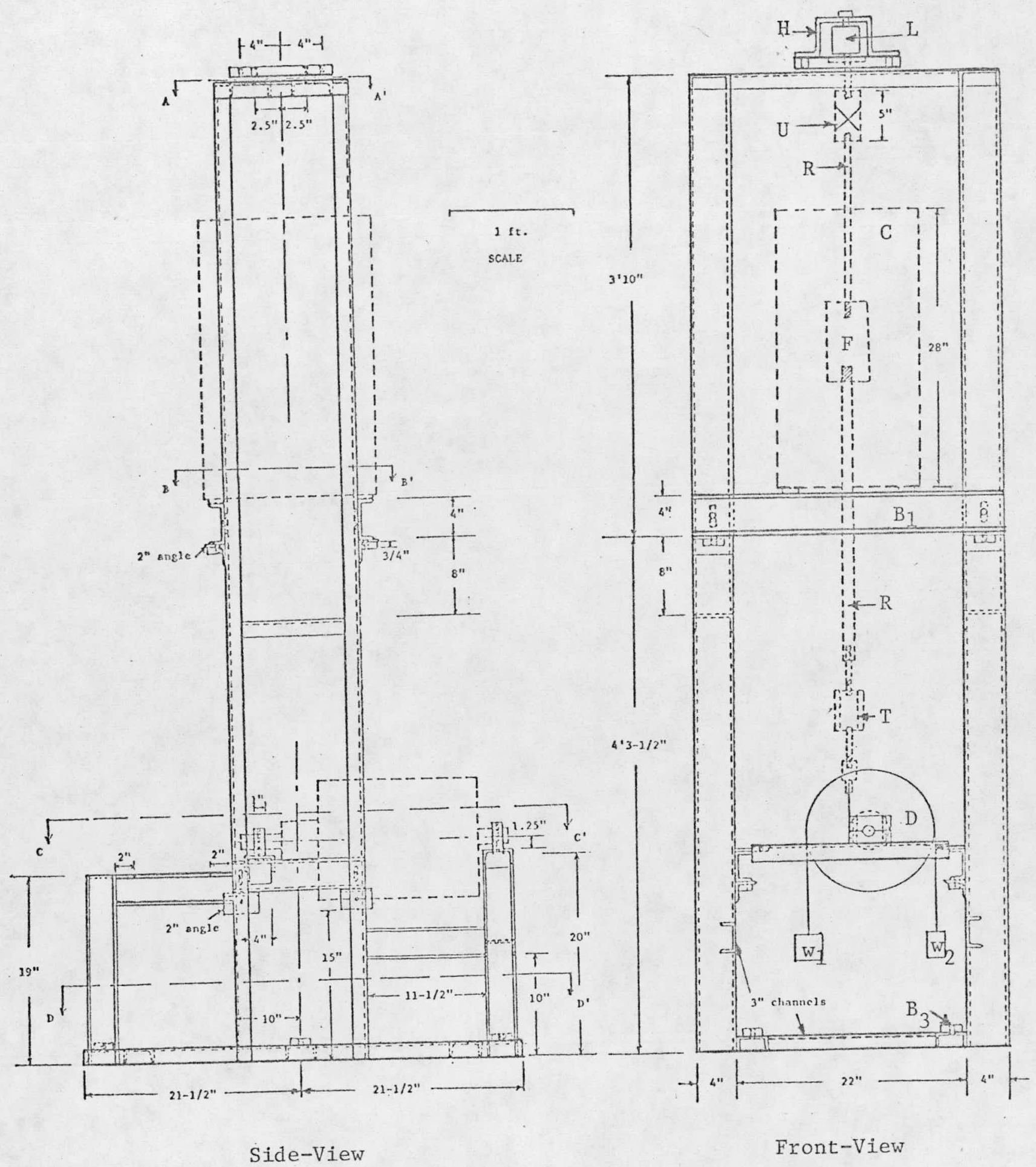

Figure 4a. Design Charts of the Loading System - Side-View and Front-View 


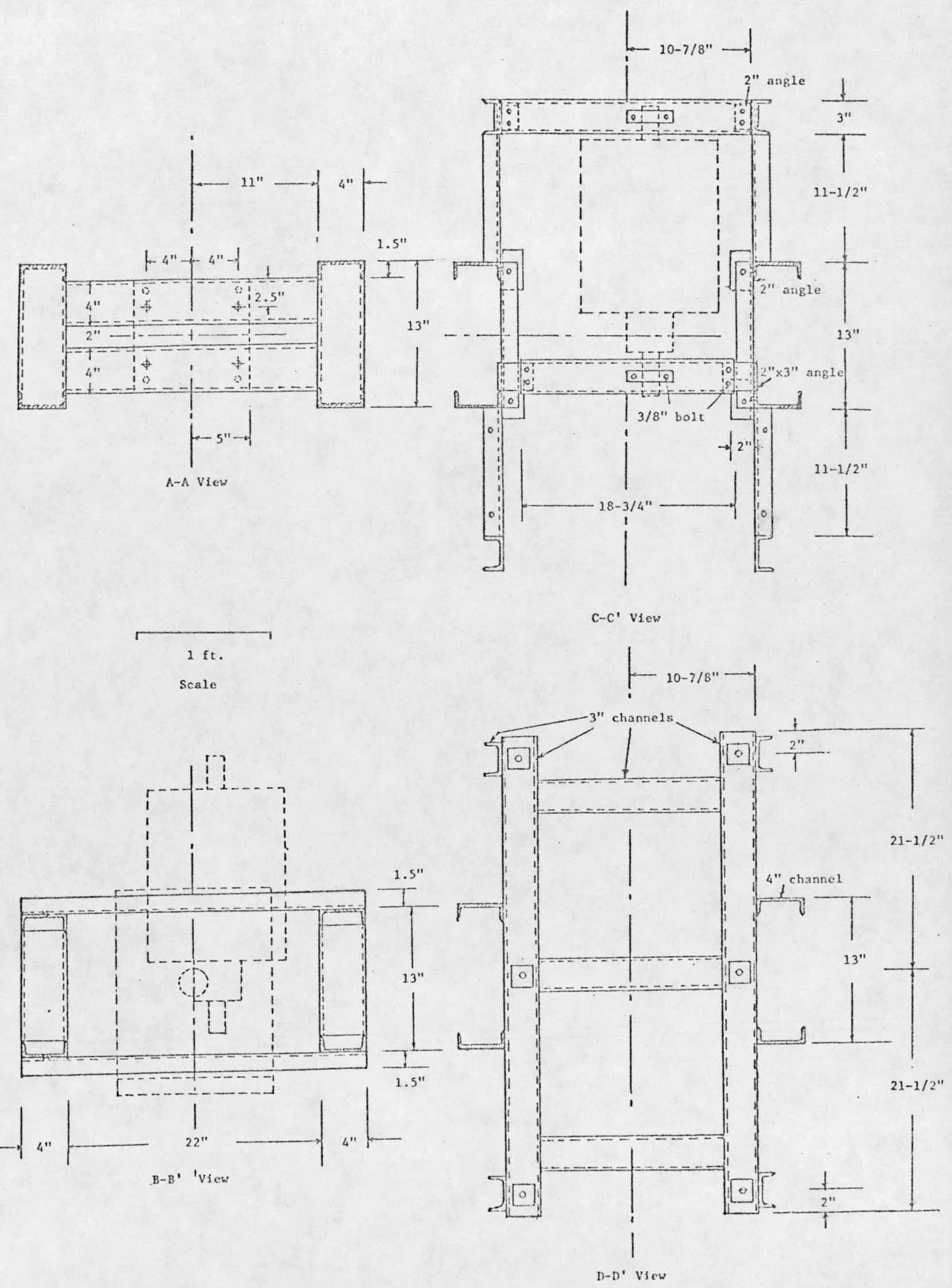

Figure 4b. Design Charts of the Loading System - Section Views 

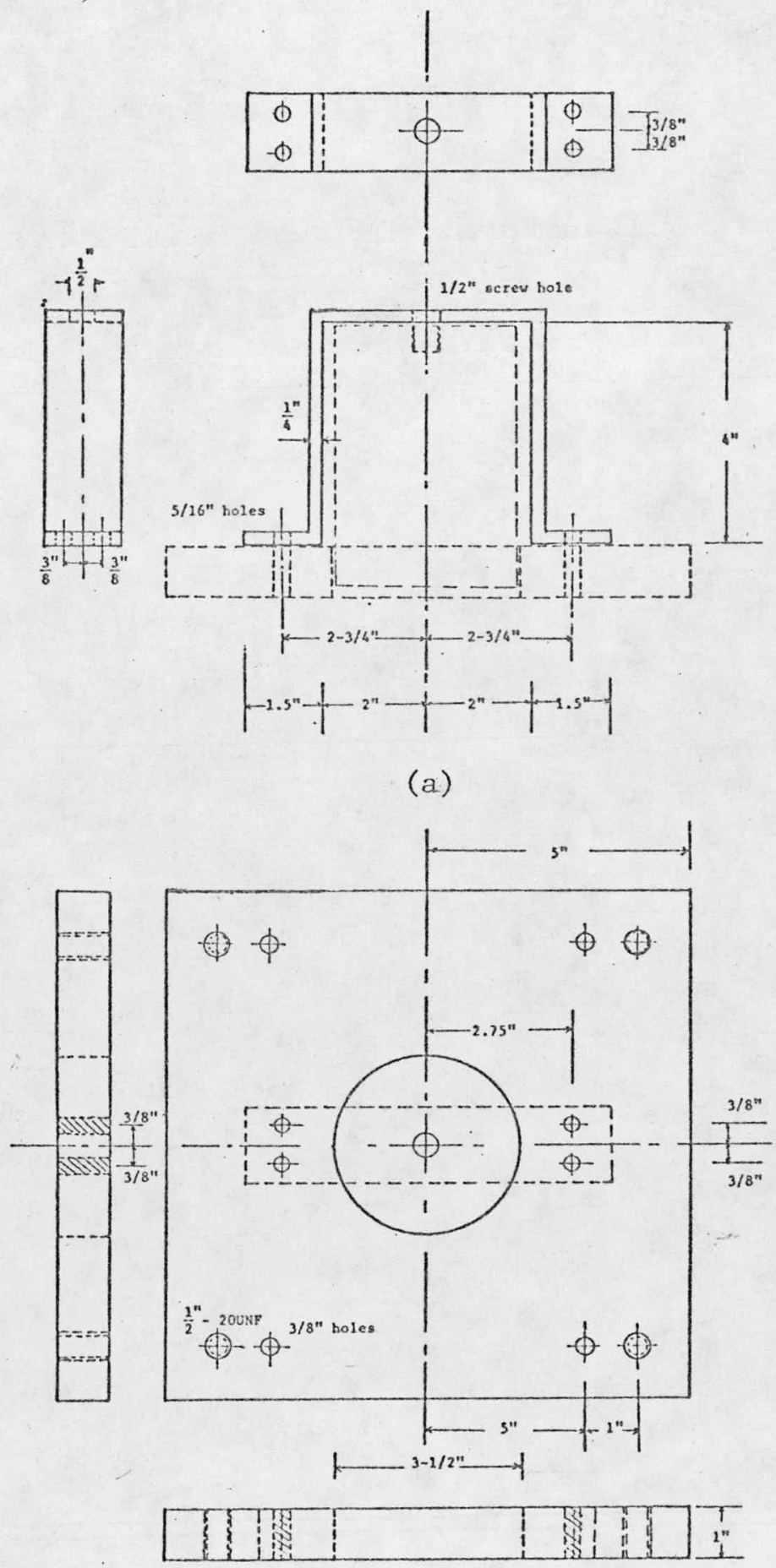

(b)

Figure 5. Load Cell Housing 


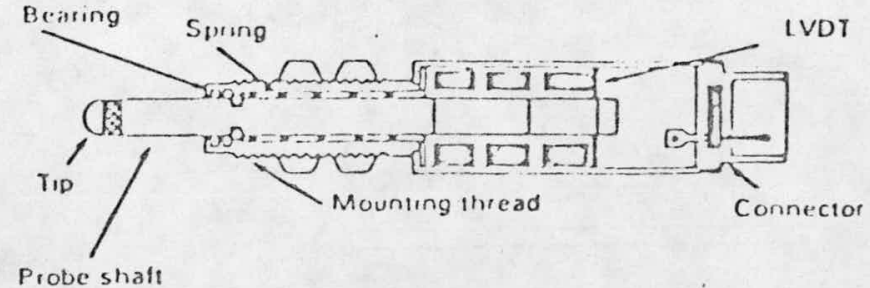

Probe shaft

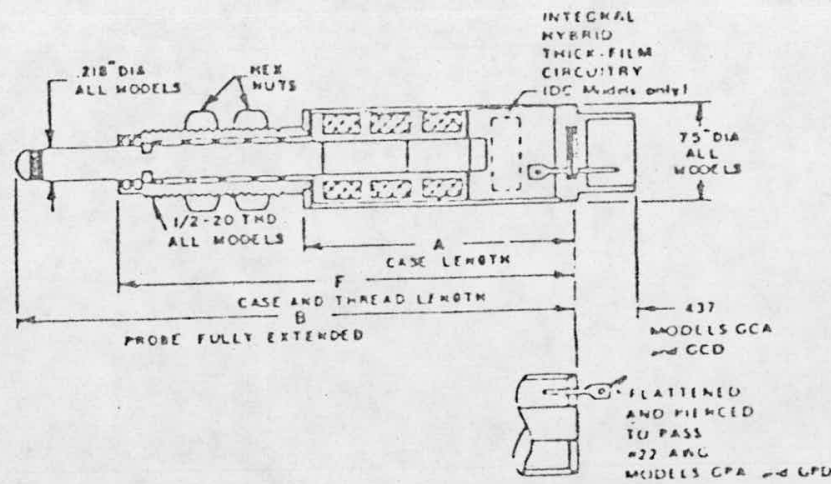

(a) Mechanical Parts
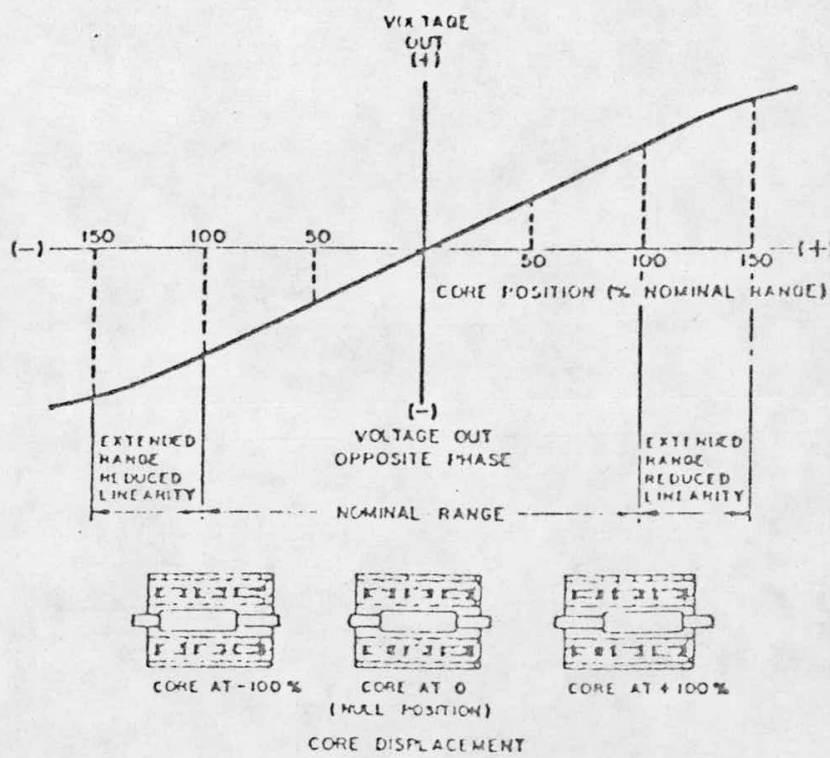

LVDT OUTPUT VOLTAGE AS A FUNCTION OF CORE POSITION

(b) Linear Range

\section{SPECIFICATIONS}

Repeatability .....0.000 025" Linearity .. $\pm 0.25 \%$ of full range Housing ....... Stainless steel Electrical Termination. . MS-type or solder-pin

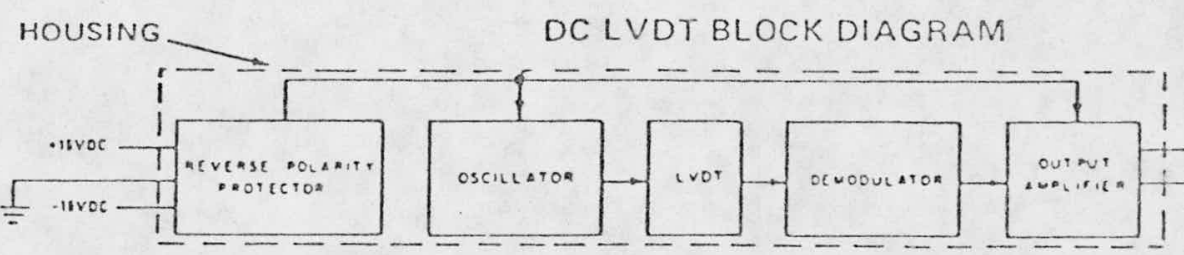

(c) Block Diagram

\begin{tabular}{|c|c|c|c|c|c|c|c|}
\hline \multirow[b]{2}{*}{ MODEL } & \multirow{2}{*}{$\begin{array}{l}\text { GAGING } \\
\text { RANGE } \\
\text { (INCHES) } \\
\end{array}$} & \multicolumn{3}{|c|}{ DIMENSIONS (INCHES) } & \multirow{2}{*}{$\begin{array}{l}\text { MECHANICAL } \\
\text { STROKE } \\
\text { (INCHES) }\end{array}$} & \multirow{2}{*}{$\begin{array}{l}\text { SPRING LOAD } \\
\text { OVER GAGING } \\
\text { RANGE IOUNCESI }\end{array}$} & \multirow[b]{2}{*}{$\begin{array}{l}\text { SENSITIVITY } \\
\text { (MVOO.001 INCH) }\end{array}$} \\
\hline & & A & 8 & $F$ & & & \\
\hline $\begin{array}{l}\text { GCD } 121.050 \\
\text { GPD } 121.050 \\
\end{array}$ & \pm 0.050 & 2.400 & 5.010 & 3.970 & 0.735 & $\begin{array}{l}3.5 \text { to } \\
5.75 \\
\end{array}$ & 200 \\
\hline $\begin{array}{l}\text { GCD } 121-125 \\
\text { GPD-121-125 }\end{array}$ & \pm 0.125 & 3.230 & 5.840 & 4.800 & 0.735 & $\begin{array}{l}3.5 \text { to } \\
5.75 \\
\end{array}$ & 80 \\
\hline $\begin{array}{l}\text { GCD } 121-250 \\
\text { GPD-121-250 }\end{array}$ & \pm 0.250 & 4.100 & 6.710 & 5.670 & 0.735 & $\begin{array}{l}3.510 \\
5.75 \\
\end{array}$ & 40 \\
\hline $\begin{array}{l}\text { GCD } 121.500 \\
\text { GPD } 121.500\end{array}$ & \pm 0.500 & 5.790 & 11.460 & 8.985 & 2.150 & $\begin{array}{l}3.2 \text { to } \\
8.0 \\
\end{array}$ & 20 \\
\hline $\begin{array}{l}\text { GCD } 121-1000 \\
\text { GPD-121-1000 }\end{array}$ & \pm 1.000 & 8.050 & 13.720 & 11.245 & 2.150 & $\begin{array}{l}3.2 \text { to } \\
8.0\end{array}$ & 10 \\
\hline
\end{tabular}

(d) Specifications

Figure 6. Details of Schaevitz DC-LVDT Gage Head 


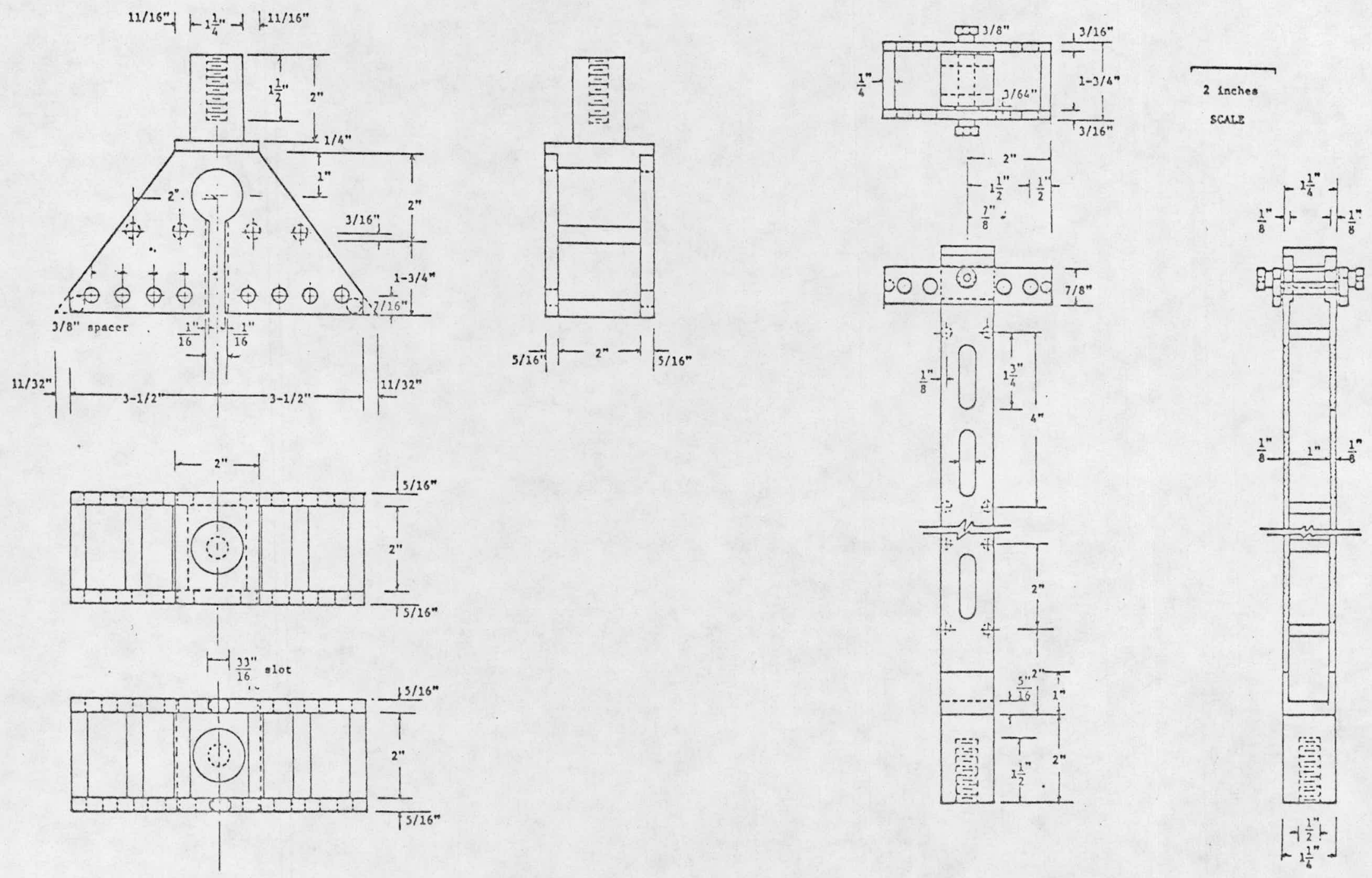

(a)

Figure 7. Load Fixture for Four Point Bending Tests

(a) Supporting Fixture

(b) Load Applying Rod 


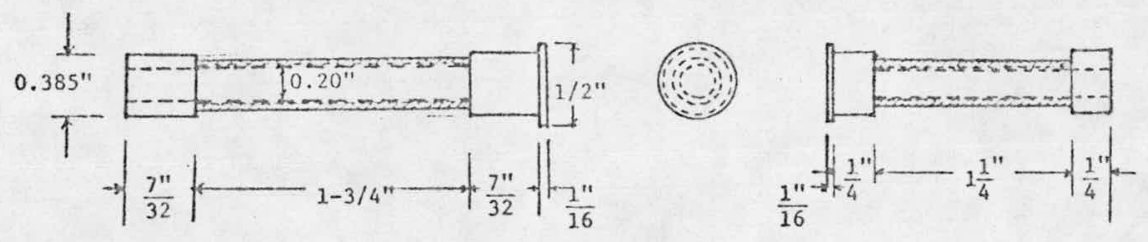

(a)
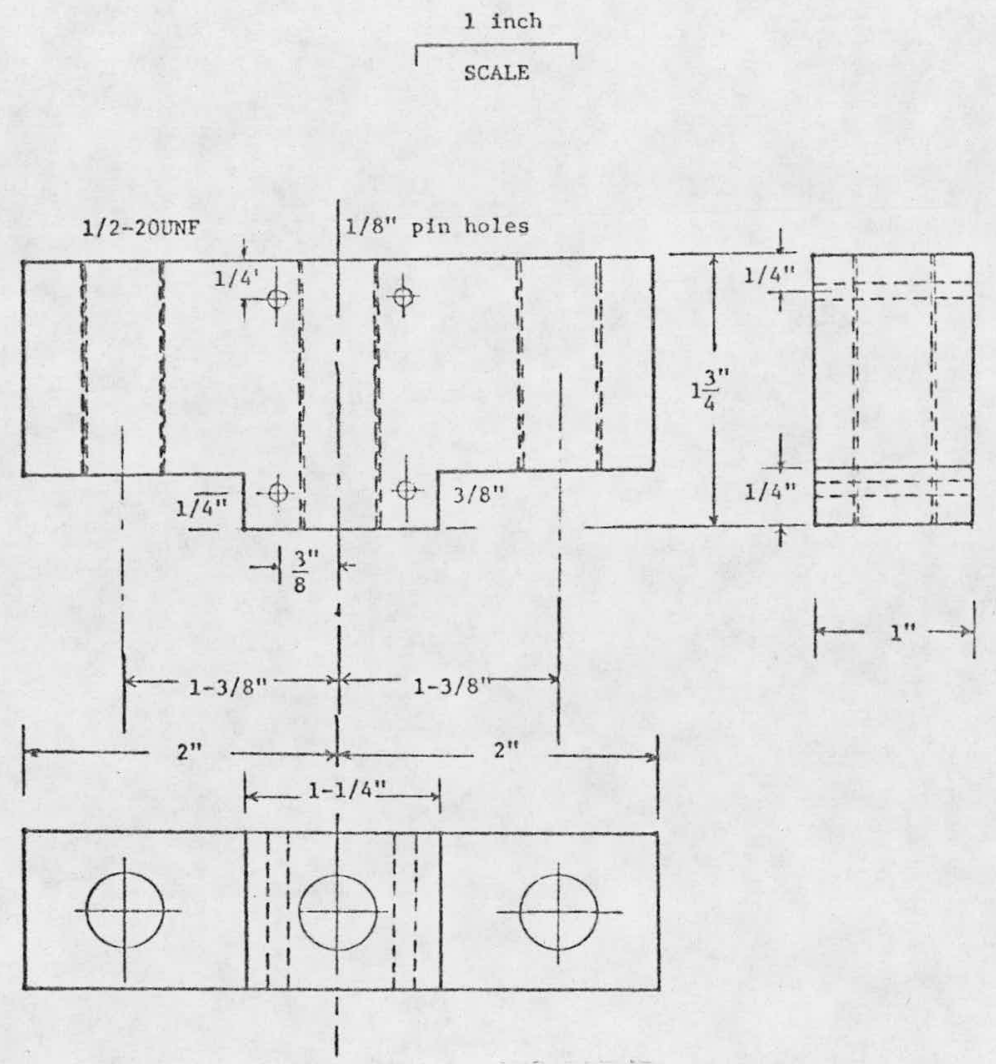

(b)

Figure 8. Accessories of Four Point Bending Load Fixture (a) Loading and Supporting Bars

(b) LVDT Holder 



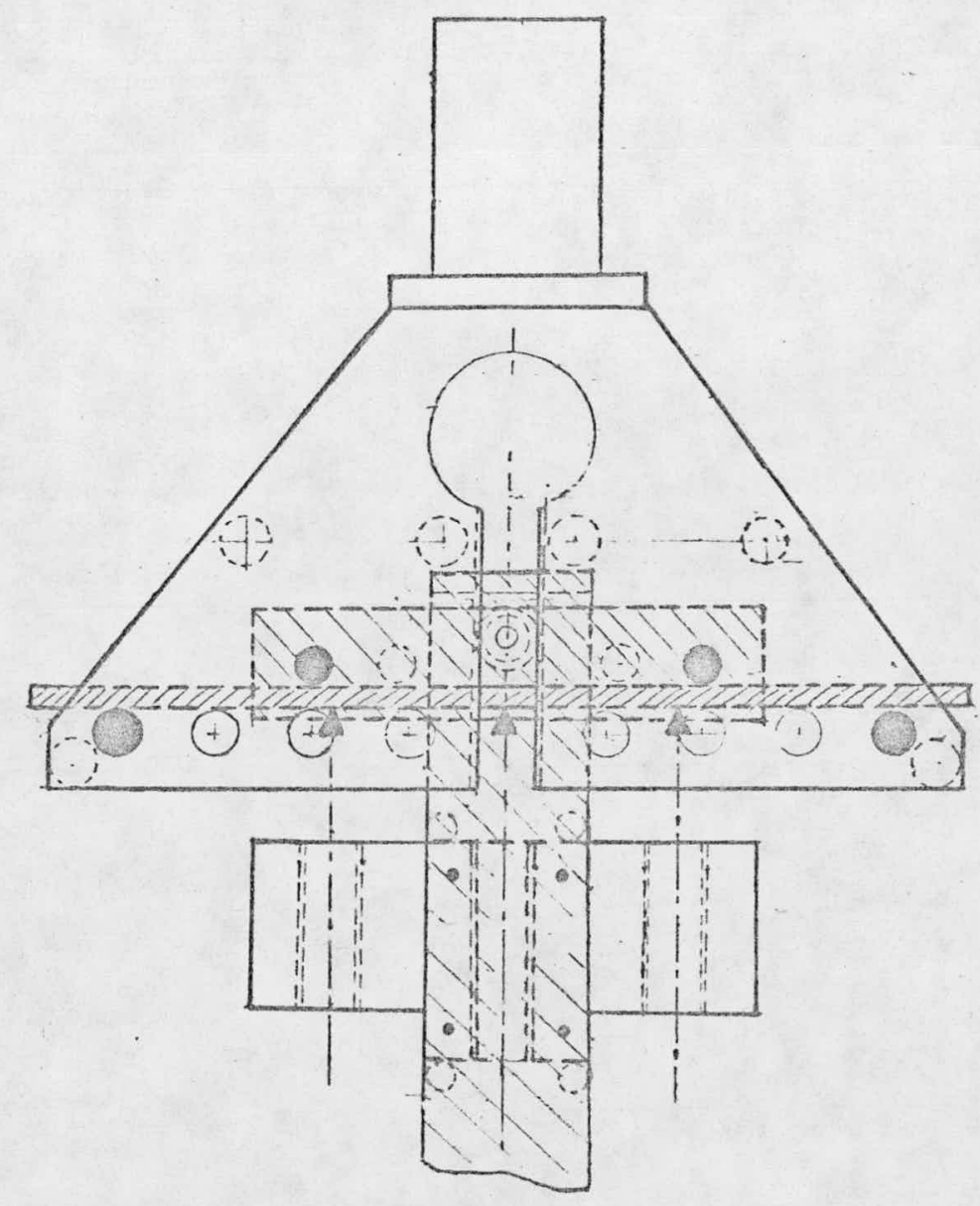

Figure 9. Test Configuration of Four Point Bending 

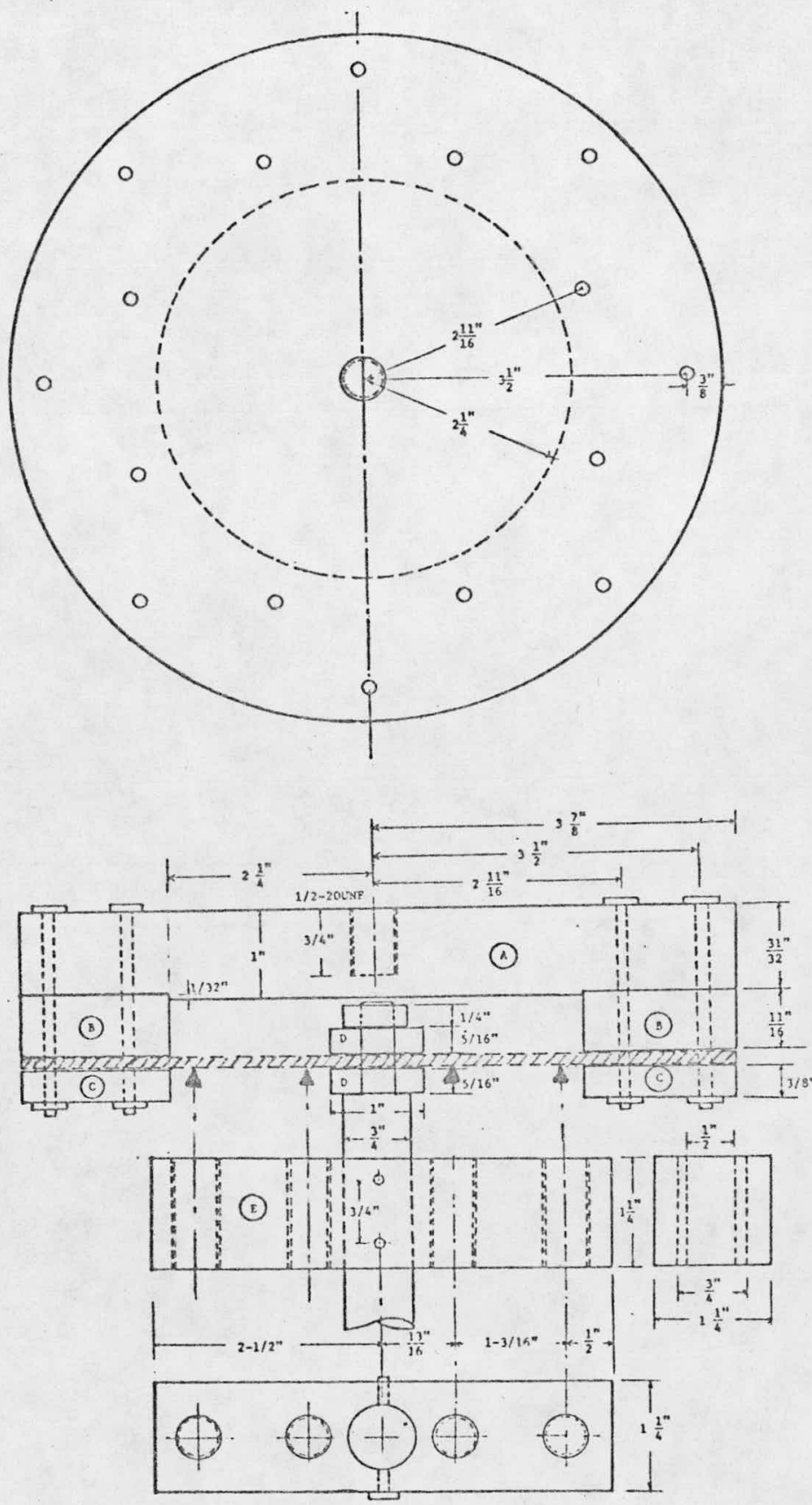

Figure 10. Load Fixture for Annular Plates 


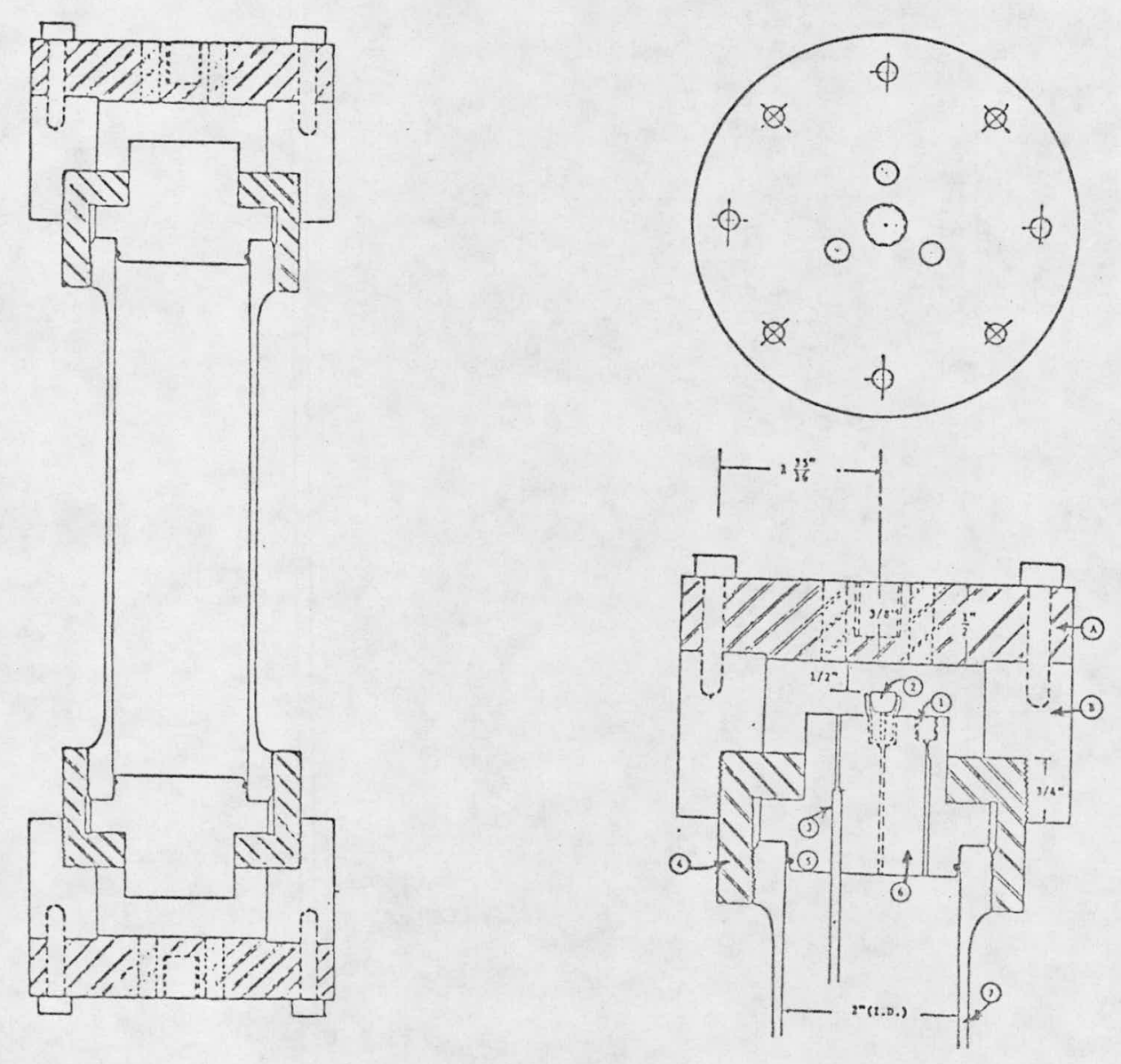
A Load Fixture Cap
B Connector
1 Pressure Connection
2 Safety Head
3 Thermocouple Well
4 Cap
5 O Ring
6 Cover
7 Specimen

Figure 11. Load Fixture for Thin-Walled Cylinders 

CALIBRATION OF S/N 1320

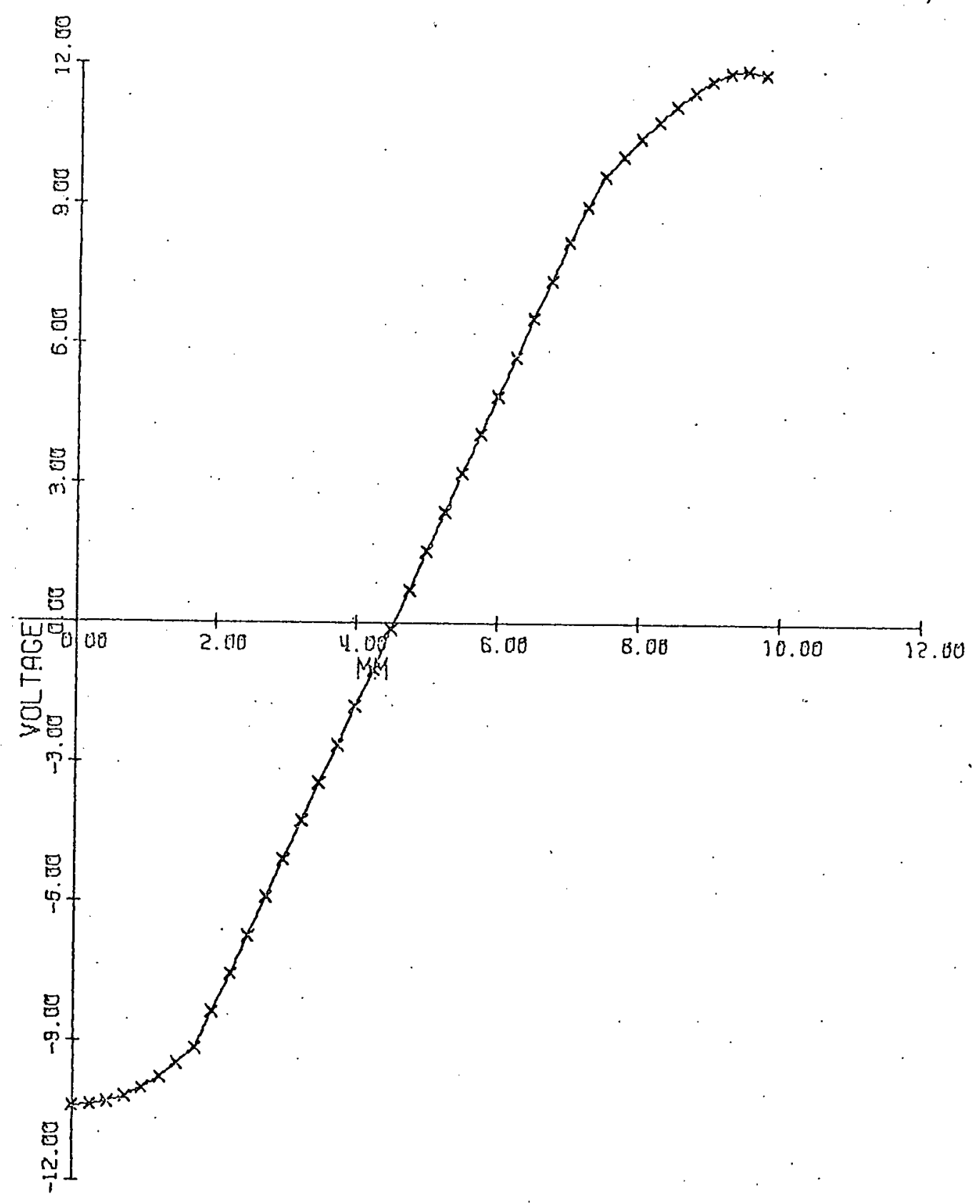

Figure 12a. LVDT Calibration ( $/ \mathrm{N}$ 1320) 


\section{CALIBRATION OF S/N 1321}

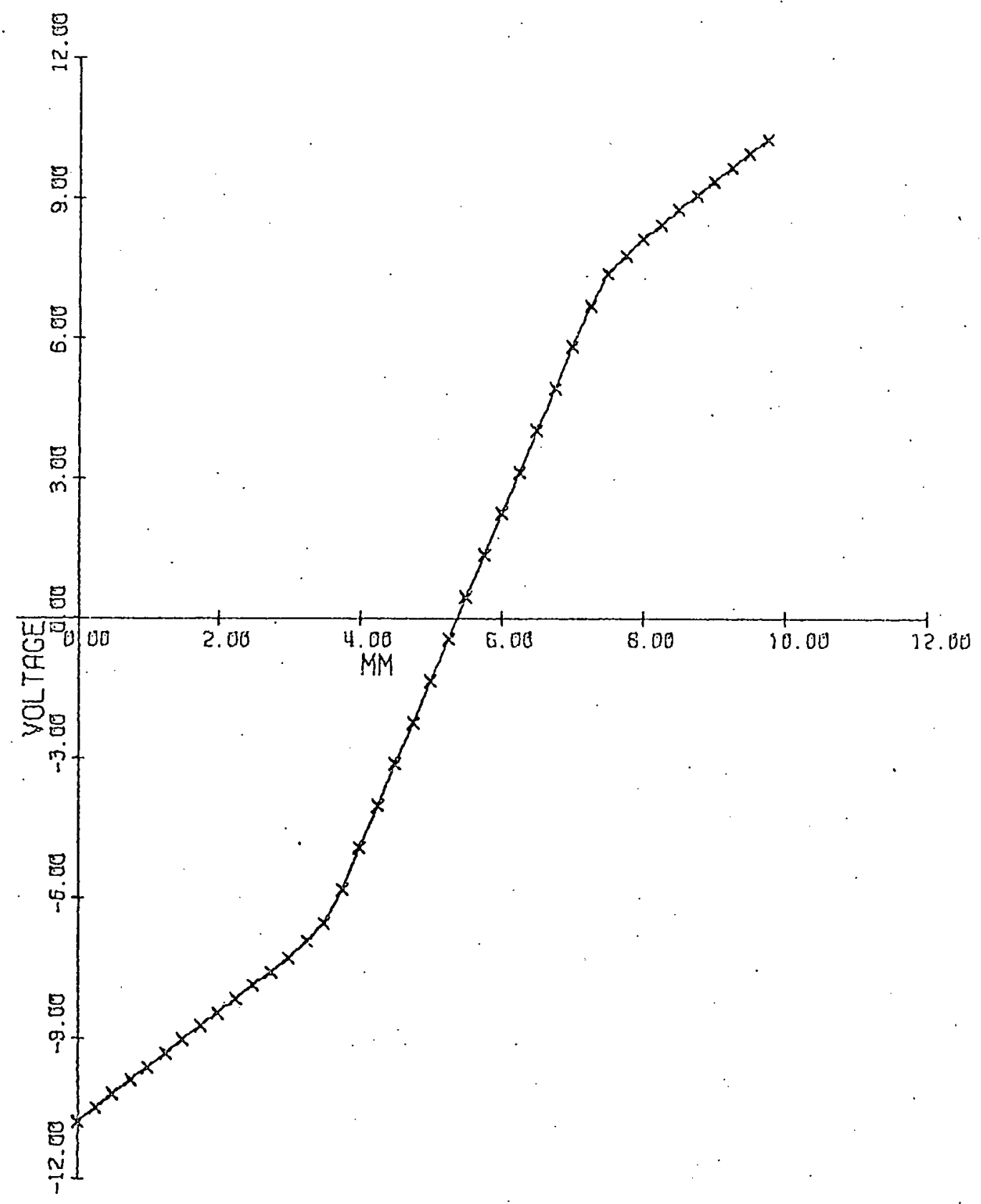

Figure 12b. LVDT Calibration (S/N 1321) 


\section{CALIBRATION OF S/N 1322}

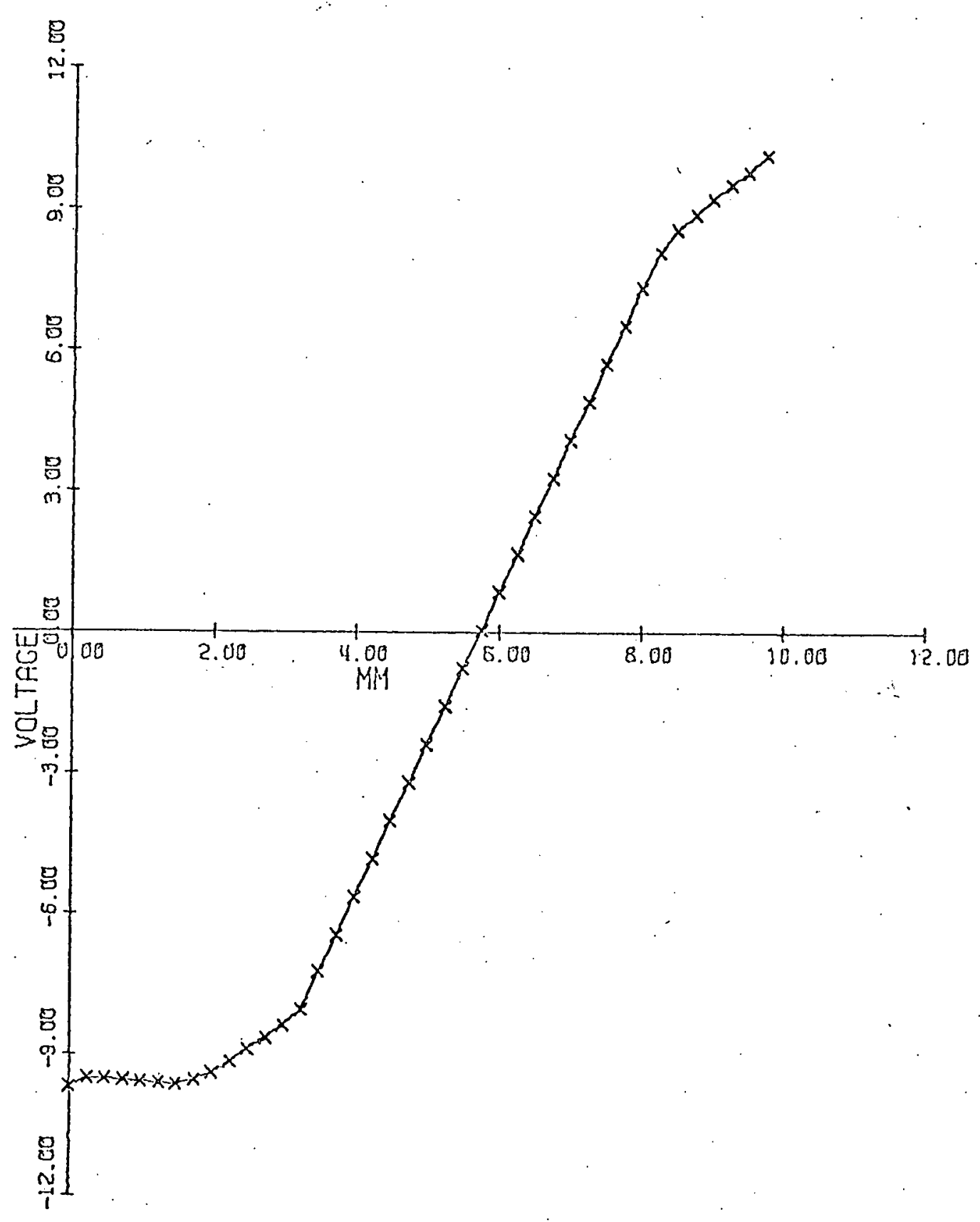

Figure 12c. LVDT Calibration (S/N 1322) 


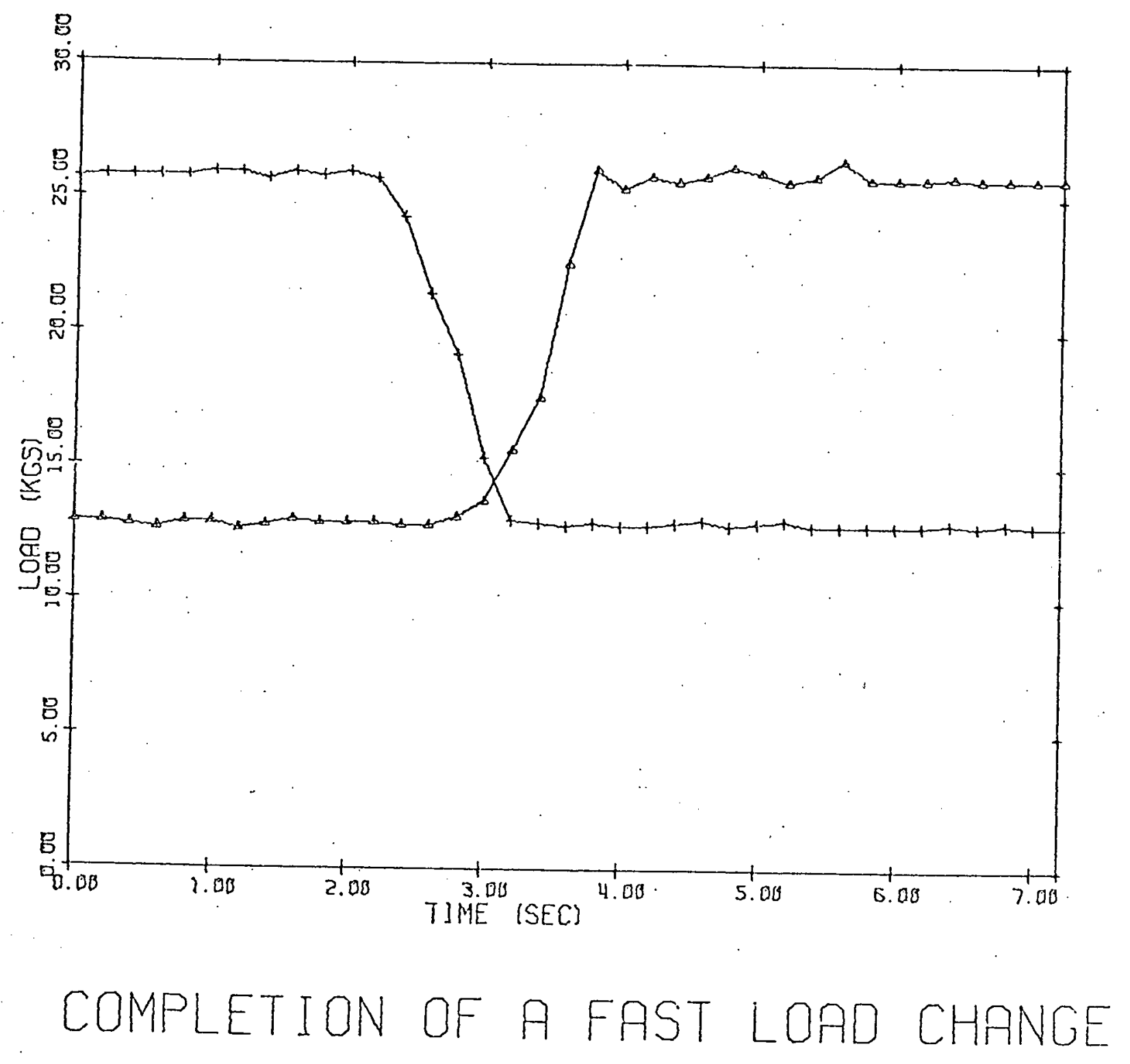

Figure 13. Completion of a Fast Load Change 


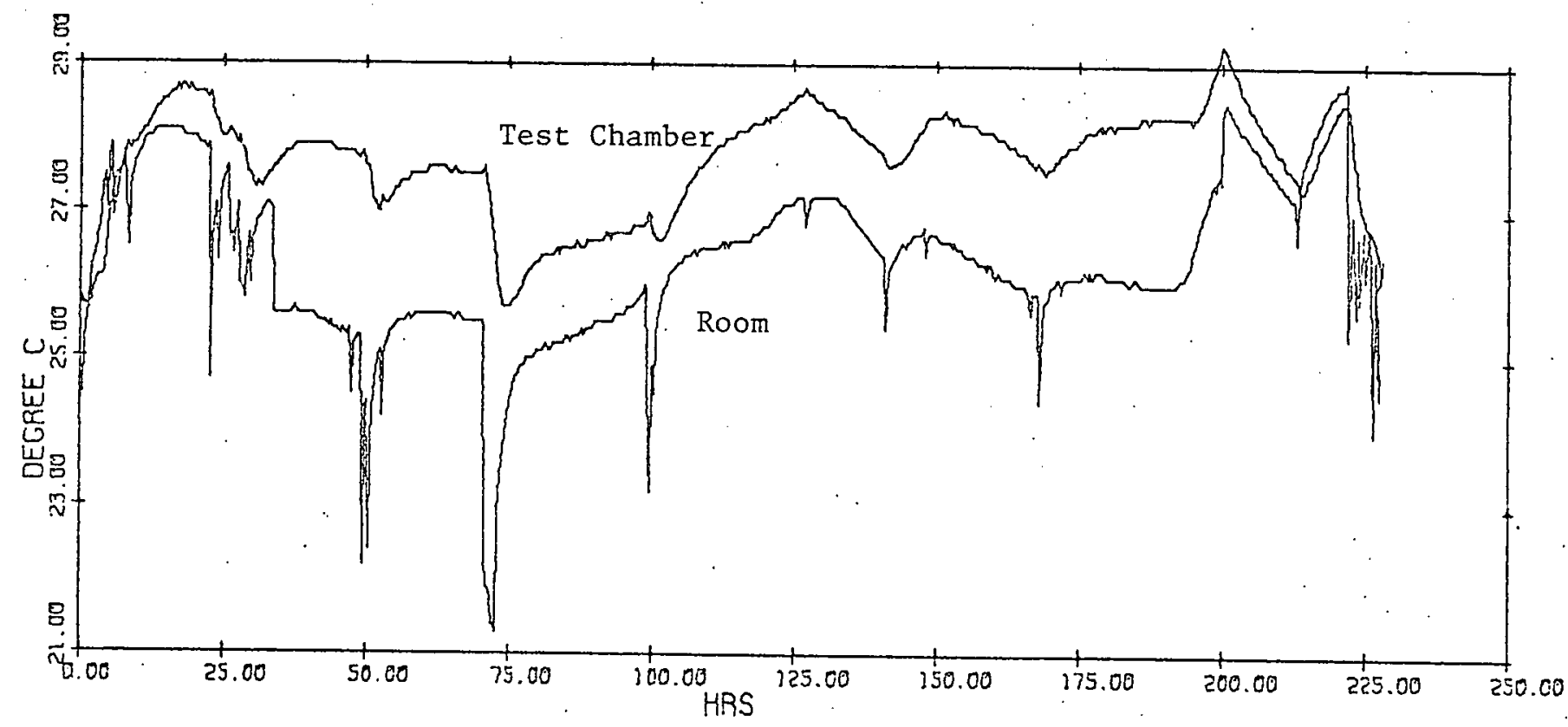

TEMPERATURE VS TIME CHARTS

Figure 14. First Test Temperature History (without control) 


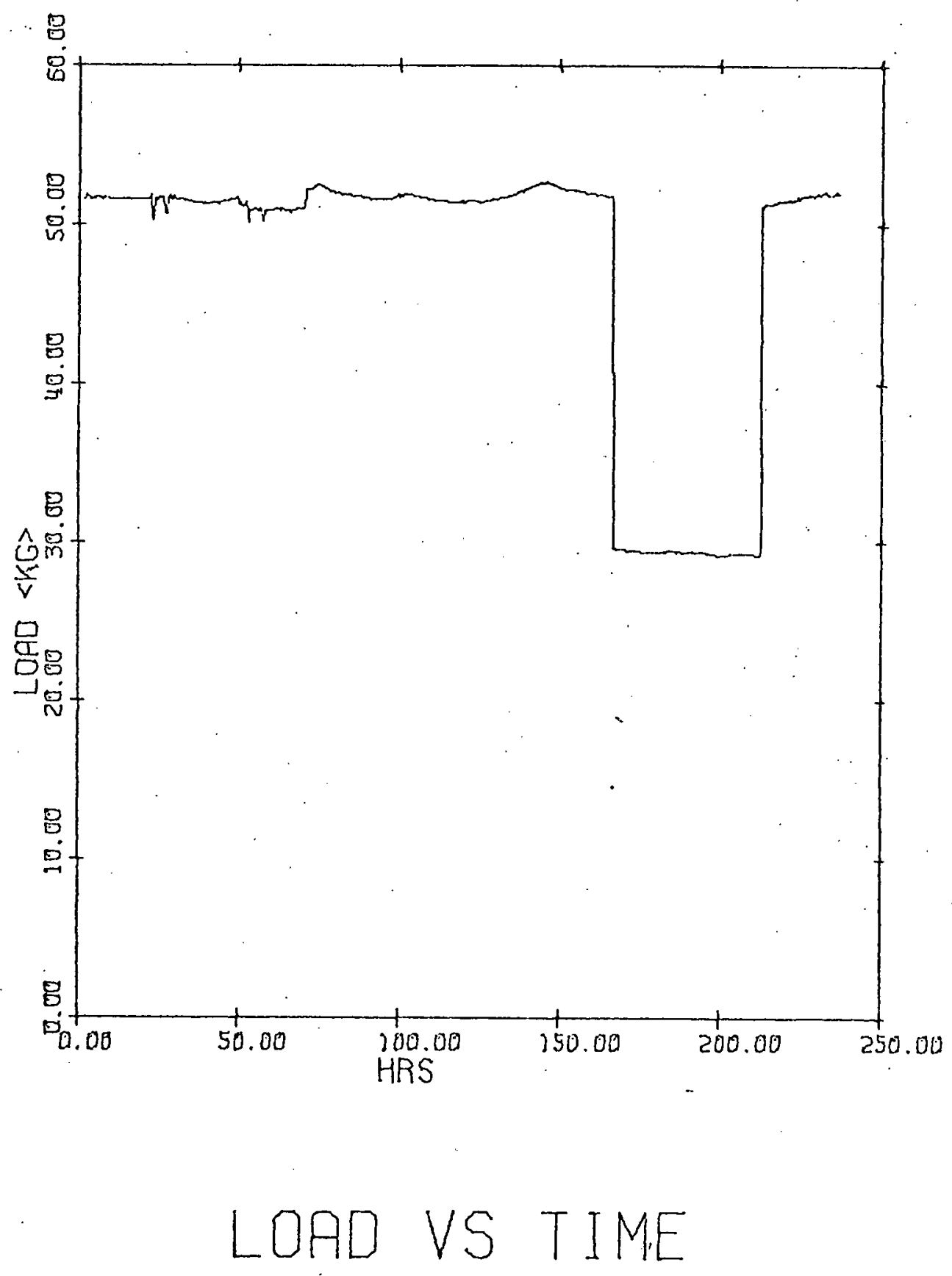

Figure 15. First Test Load History 


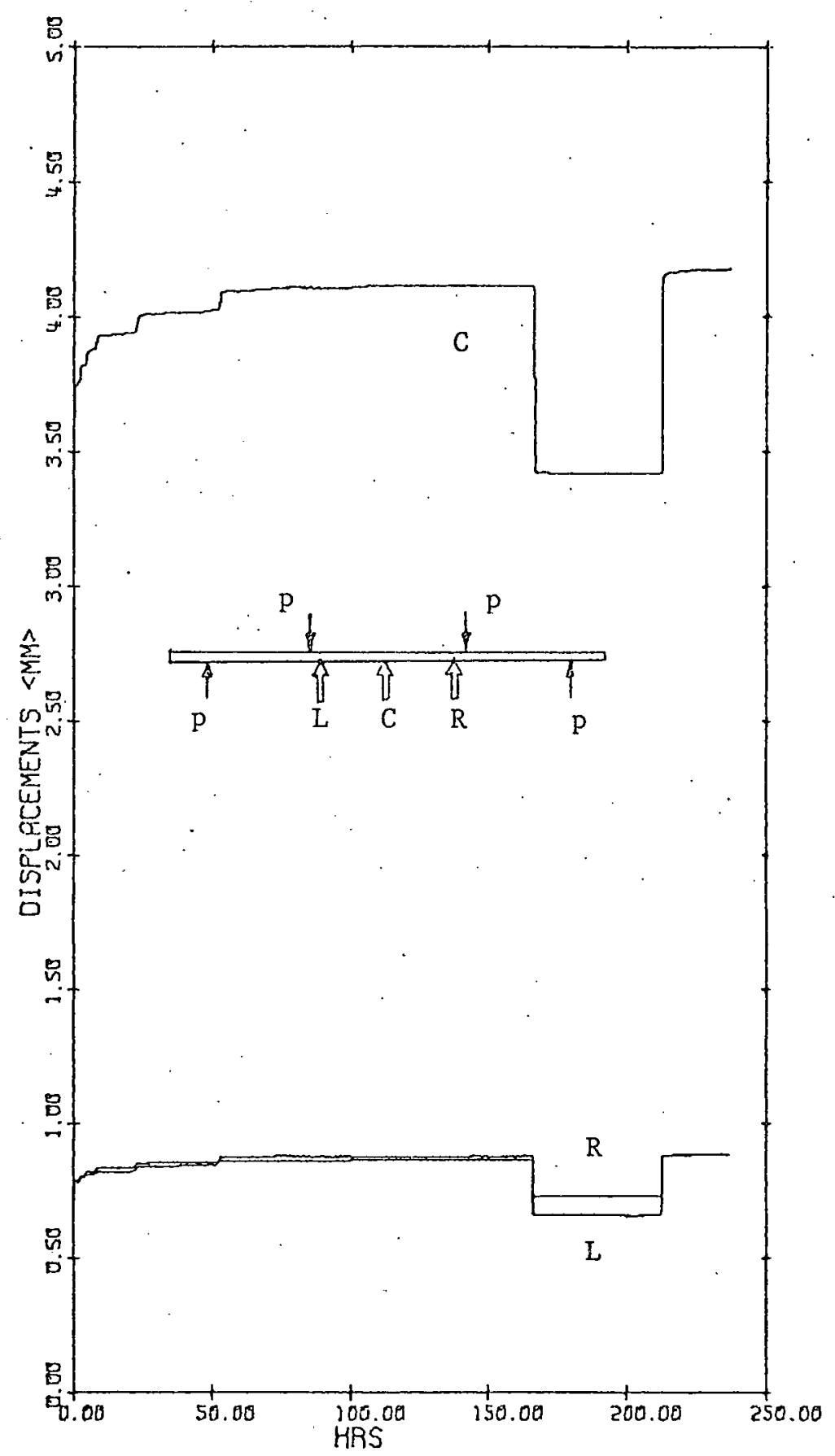

\section{DISPLACEMENTS OF ALL LVDTS}

Figure 16. First Proof Test Displacements

(L, C, R are LVDT Positions.) 


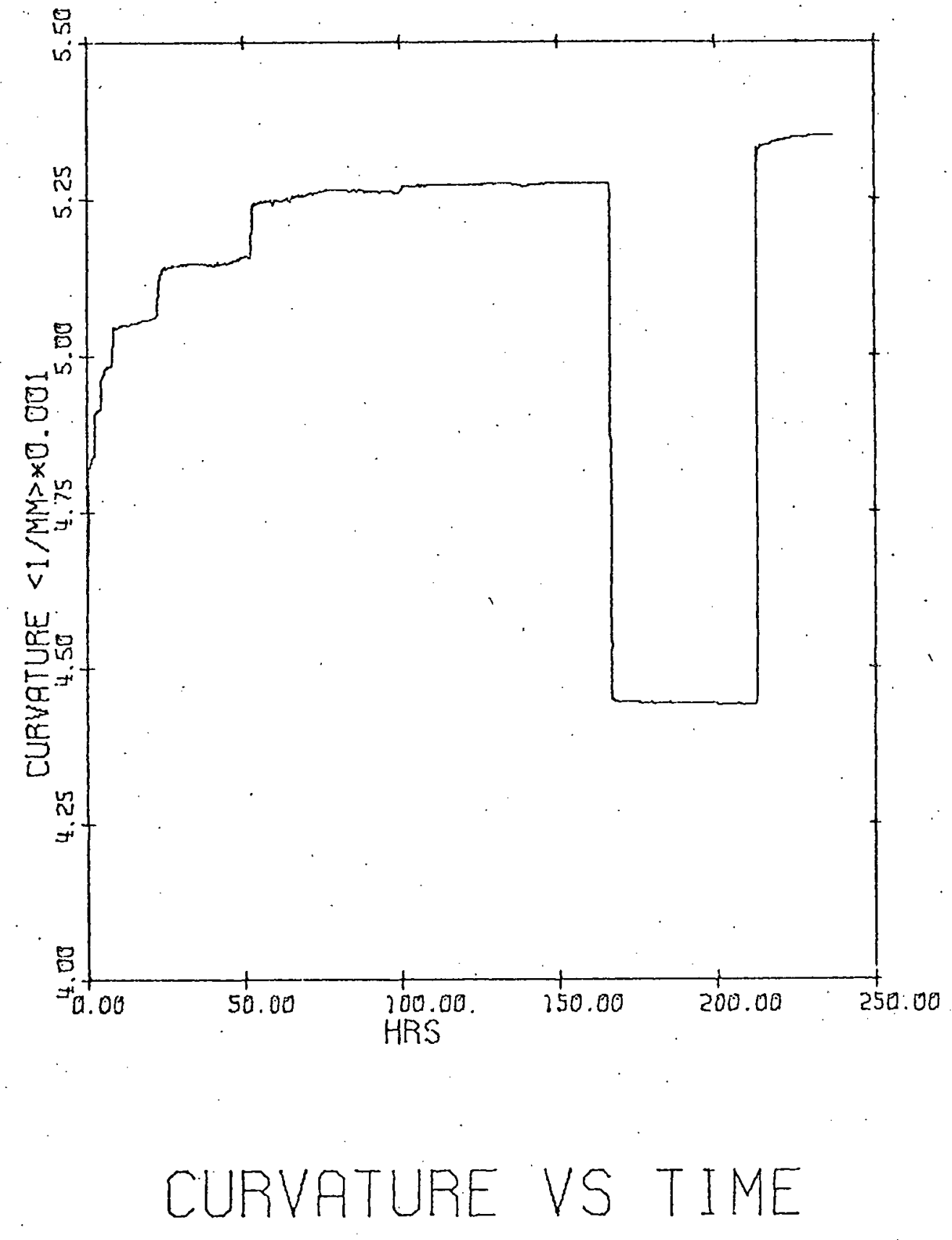

Figure 17. First Proof Test Curvature 


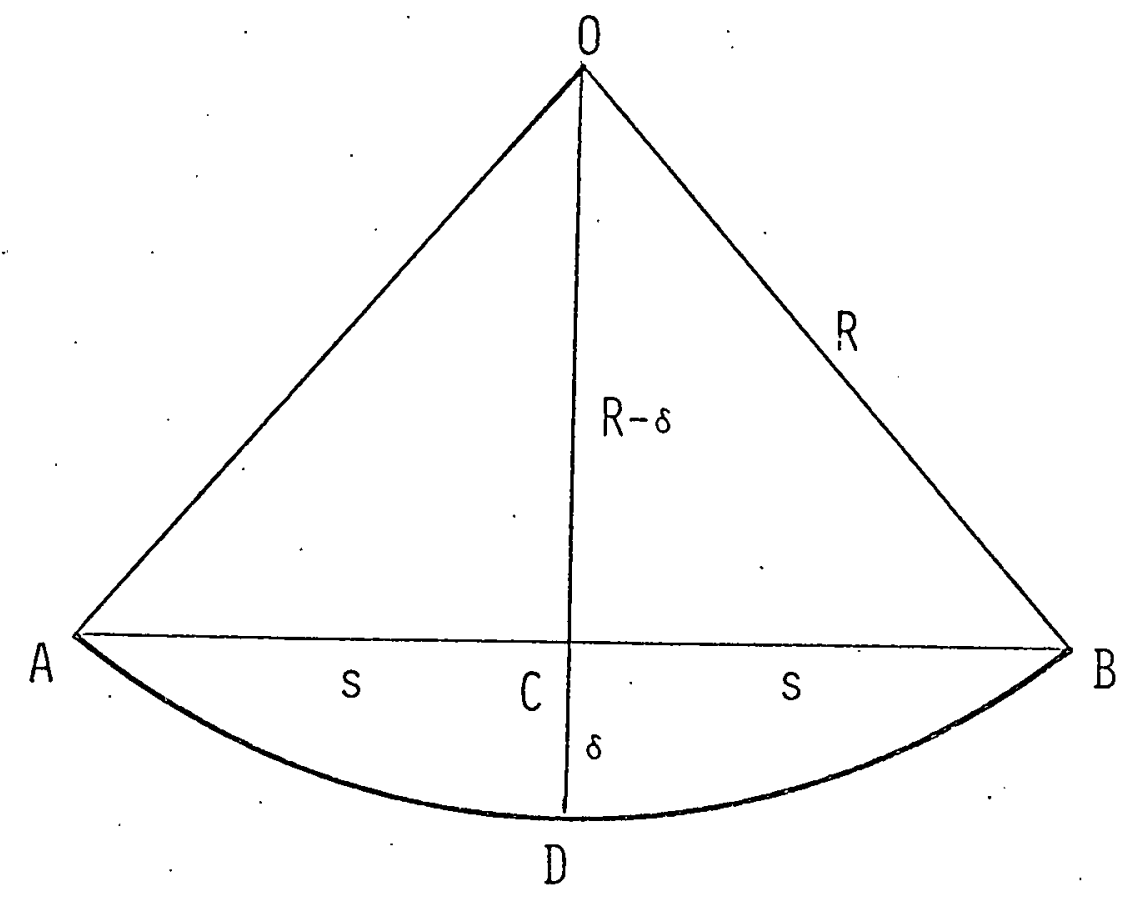

Figure 18. Curvature Calculation 


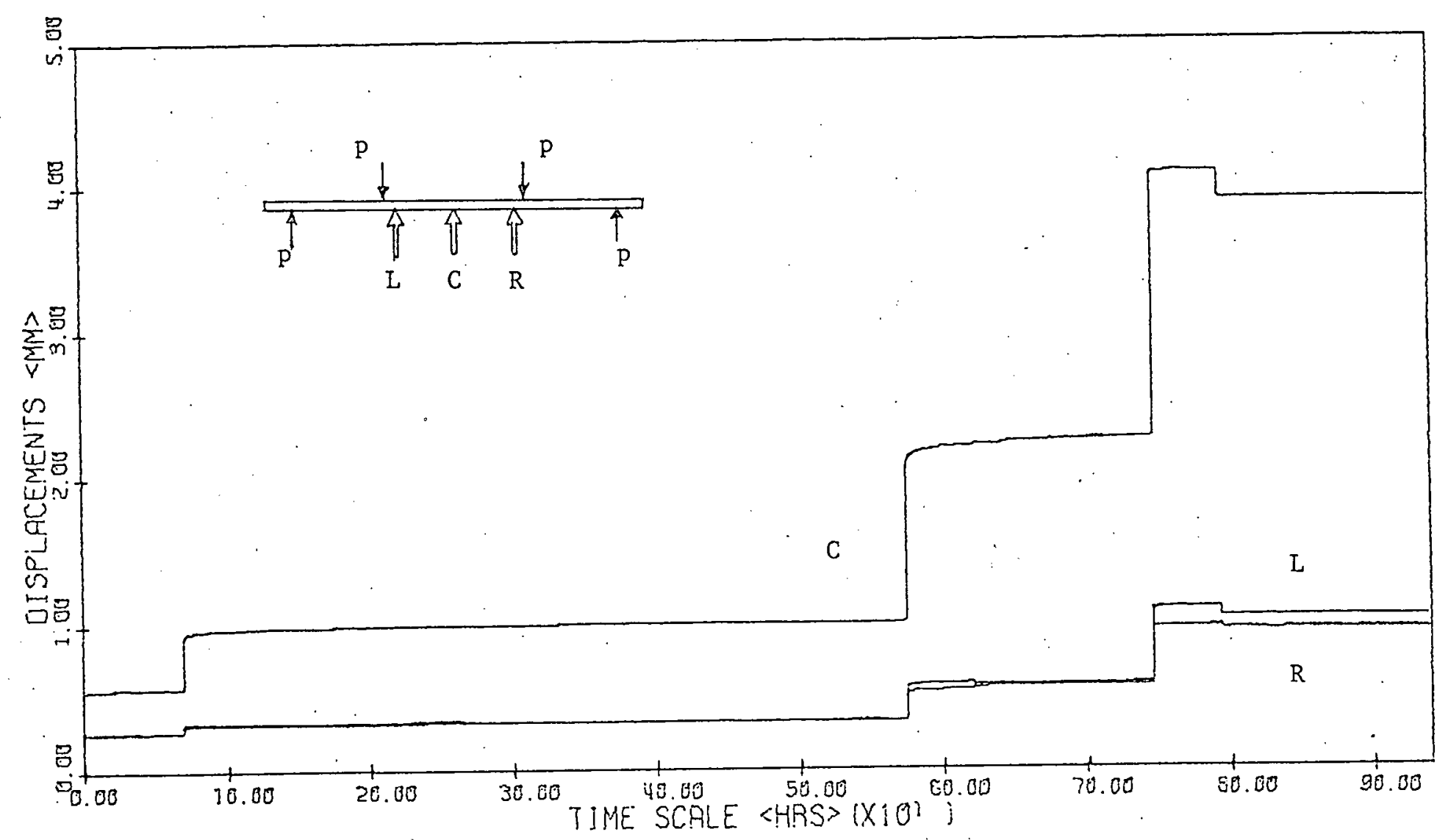

Figure 19. Second Proof Test Displacements

( $\mathrm{L}, \mathrm{C}$ and $\mathrm{R}$ are LVDT Positions.) 


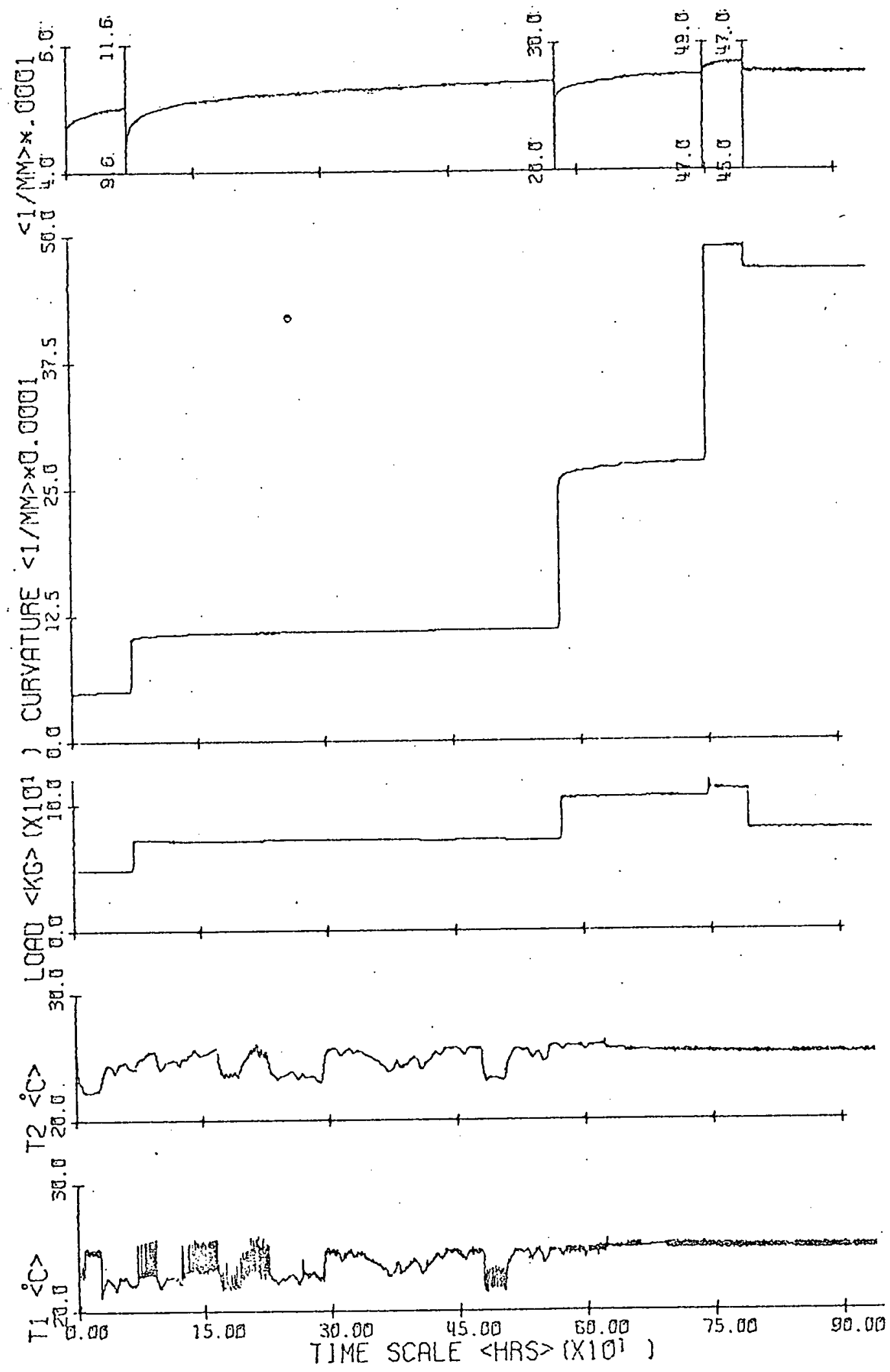

Figure 20. Second Proof Test Temperature, Load and Curvature. 